\title{
Corporate Restructuring and R\&D: A Panel Data Analysis for the Chemical Industry
}

\author{
Ashish Arora \\ Heinz School of Public Policy \\ Carnegie Mellon University \\ Marco Ceccagnoli \\ Heinz School of Public Policy \\ Carnegie Mellon University \\ Marco Da Rin \\ Dipartimento ‘G. Prato'(Università di Torino) and IGIER
}

September 2000

\footnotetext{
Financial support from the European Commission for the project `From Science to Products: A green Paper on Innovation in the Chemical Industry' (SOE1-CT97-1059) is gratefully acknowledged. We thank other participants in the project for useful comments. Address correspondence to: Ashish Arora or Marco Ceccagnoli, Heinz School of Public Policy, Carnegie Mellon University, Pittsburgh (PA)., 5000 Forbes Ave, Pittsburgh PA 15213-3890, ashish@andrew.cmu.edu, marcoc@andrew.cmu.edu, or to Marco Da Rin, IGIER, via Salasco 5, 20136 Milano (Italy). Phone (39-02) 5836.3379, Fax (39-02) 5836.3302, E-mail: marco.darin@uni-bocconi.it.
} 


\begin{abstract}
We contribute a novel approach to the existing literature on the effects of restructuring on R\&D investment by focussing on a single industry, chemicals. The chemical industry is very research intensive and has experienced thorough restructuring since the early 1980s. By focussing on a single industry we are able to identify the technological and R\&D features of its segments. This is important, since there is evidence that restructuring affects $R \& D$ differently in businesses with different technological features. However, no study so far has provided a systematic inquiry into this link. Using a panel of 535 European, American, and Japanese firms for the years 1987-1997 we find restructuring to be an important component in the observed changes in $R \& D$ intensity. We show that restructuring affects R\&D both through changes in size and through changes in the composition of business portfolios, and that these effects differ across industry segments.
\end{abstract}




\section{Introduction}

Investment in research and development $(R \& D)$ is as an important source of long-term growth for industrial economies, and the economics of R\&D is an intensely researched topic, see Tirole (1988) for a theoretical survey and Cohen (1995) for a recent empirical survey. Much attention has gone into the determinants of the R\&D investment decision, both theoretically and empirically. However, in mature economies, firms and industries increasingly evolve through restructuring. Restructuring at the firm level entails changes in the composition of both capital and labor, and in particular the divestiture and acquisition of productive assets. Restructuring at the level of the industry entails the entry and exit of firms through takeovers, mergers and acquisitions, i.e. sales and purchases of whole businesses. It is then important to understand what effect restructuring has on $R \& D$, but the topic has received relatively little attention so far. In this paper we provide a study of firm-level restructuring which sheds new light on how firms change their R\&D investment as a result of changes in their business portfolios.

In the late 1980s, a number of empirical studies have analyzed on the effects of restructuring on R\&D. ${ }^{1}$ These efforts were motivated by the suspicion that the increased takeover activity among U.S. firms in the early 1980s might have induced 'managerial myopia' (Stein (1988)), and thus a decrease in long-term investments such as R\&D.

The brunt of this exercise was done by Bronwyn Hall $(1988,1990)$. Using information on U.S. listed manufacturing companies, she examined the determinants of acquisitions, making some important points. ${ }^{2}$ First, acquisitions by public companies do not result in any systematically significant decline in $R \& D$ spending, nor there is any significant difference between firms actively restructuring through acquisitions and inactive firms. Moreover, the difference in $R \& D$ intensity-defined as the ratio of $R \& D$ to salesbetween acquiring and acquired firms is statistically insignificant, while the population of acquiring firms experienced a decline in $R \& D$ intensity (relative to their industry) over the 1980s. Second, R\&D intensity marginally declines following an acquisition by a private company (a 'going private' transaction, such as a leveraged or management buy-out), a type of acquisition which occur prevalently in industries where $R \& D$ intensity is low to start with. ${ }^{3}$ Third, whether induced by the acquisition or by other events, large increases in leverage (i.e. larger than 50\%) resulted in significant decreases in R\&D intensity. For firms not engaged in going private transactions this effect was sizeable: on average about 0.8 percent of sales. Finally, $R \& D$ is a poor predictor of acquisitions, with the notable exception of the cases when a firm was being taken private.

Hall (1994) made a further point, which motivates our study. She showed that the pressure to restructure is not constant across industries, but depends on the pace of technological change, a fact also documented by Blair and Litan (1990) and Blair and

\footnotetext{
${ }^{1}$ Hall (1992) provided a justification for why R\&D should be particularly vulnerable to financial considerations and a first inquiry into its empirical justification.

${ }^{2}$ These results were extended to the mid 1990s by Hall (1999).

3 Kaplan (1989), Licthenberg and Siegel (1990), and Smith (1990) reach similar conclusions using different samples.
} 
Schary (1993). ${ }^{4}$ Hall found that the four categories used by Chandler (1990) to partition manufacturing industries-high-, low- and stable- (with short and long lifetime horizons) technology — are good predictors of acquisition probabilities. Firms with lowor stable-, short horizon, technology are the likeliest candidates for an acquisition, especially through a going private transaction. Firms with stable, long horizon, technology are likeliest to take on large leverage and to reduce physical investment. On the contrary, the effect of leverage on R\&D does not differ significantly across the four categories.

These contributions still represent the locus classicus for the analysis of how corporate restructuring affects R\&D investment. However, they do not address some important questions. In particular, they establish causal links using data for the U.S. manufacturing sector as a whole, but do not look into the effect of the reallocation of asset portfolios across different segments within an industry. The intensity of restructuring varies across industries, as does its effect on R\&D investment. Since most industries are typically made up of technologically heterogeneous segments, variation in the effects of restructuring on $\mathrm{R} \& \mathrm{D}$ is likely to be experienced also within an industry. It is then important to bring the analysis at the level of the industry and to look into how R\&D reacts to restructuring at both segment and firm level. In particular, firm level data can be exploited to relate corporate restructuring to changes in R\&D investment taking into account firms' technological (re)positioning. This is our contribution.

We focus on a single industry, chemicals, and study the impact of restructuring on R\&D and capital expenditure. ${ }^{5}$ There are several important reasons to focus on chemicals ${ }^{6}$ :

(1) First, the chemical industry is capital and R\&D intensive, so that changes in a firm's industrial portfolio may require large transactions in terms of plants, as well as in terms of R\&D strategy. This makes this industry particularly suitable for our analysis;

(2) Second, there have been some important and clearly identifiable shocks to the industry since the 1970s. The oil shock exposed overcapacity in petrochemicals; the rise of biotechnology severed the link between chemicals and pharmaceuticals, and created life sciences as a separate industry; the dissemination of maturing process technology worldwide made 'specialty' chemicals more lucrative than 'commodity' chemicals. The far reaching nature of these shocks has resulted in continued pressure for restructuring, giving us a precious chance to study the effects of ongoing structural changes;

(3) Third, focussing on chemicals allows us to identify several segments with distinct technological characteristics, and thus to assess precisely the nature of restructuring;

(4) Lastly, chemicals have been a truly global industry since long; Hence, looking at chemicals allows us to grasp effects which go beyond national idiosyncrasies.

\footnotetext{
${ }^{4}$ Fusfeld (1987) and Miller (1990) provide a number of case studies of the effects on R\&D of the restructuring underwent by large corporations in different industries.

${ }^{5}$ The papers collected in Arora, Landau and Rosenberg (1998), and the references cited therein, provide a thorough account of the evolution and structure of the industry.

${ }^{6}$ Notice that Hall (1994) classified pharmaceuticals as a high-tech industry, while chemicals (at large) as a stable, long-horizon, technology industry - the category most likely to undergo restructuring and to subsequently experience a reduction in physical investment.
} 
We thus provide a fresh and fine-grained perspective. Unlike the bulk of the previous work in this area, we analyze not only acquisitions, but also divestitures. Also, we consider not just acquisitions of entire firms, but also of single divisions and businesses. Since the bulk of industrial restructuring in chemicals - as well as many other industries with multi-business firms-involves assets sales and divestitures at the business or product level, our analysis provides further insights than the earlier literature on acquisitions. Moreover, we consider a sample of firms from the U.S., Europe, and Japan, so as to get a broader view of the dynamics of corporate restructuring, a view consistent with the global nature of the chemical industry. And we explore the effects of restructuring for the 1990s, which was an extremely intense period of restructuring in chemicals. $^{7}$

We assemble a unique database which covers the years 1987 to 1997 , and which contains financial and company information for 535 North American, European and Japanese chemical firms for whose acquisitions and divestitures we also gather information. While our sample is biased towards North American firms, which constitute $58 \%$ of the sample, it nonetheless includes most of the large chemical companies from Europe and Japan.

Our main result is that restructuring does matter for R\&D investment. Net acquisitions in $R \& D$ intensive industry segments have a positive and significant effect on $R \& D$ investment, a result robust to different specifications and samples. We get further insights once we look into variations across industry segments: By looking into a single industry and at its segments, we are able to get a finer appraisal of the effects of changes in portfolio composition on R\&D. For example, we find that the significance of net acquisitions varies across specifications and samples. We also find that the elasticity of $\mathrm{R} \& \mathrm{D}$ with respect to sales is less than one, and varies widely across industry segments.

Financial variables like debt or cash flow do affect $R \& D$, but not the effect that restructuring has on R\&D. This result complements Hall's (1990) finding that the effect of leverage on R\&D intensity does not change whether a firm is an active acquirer or not. Finally, we find that the effect of restructuring on R\&D and capital investments is markedly different, contrary to the findings of Hall (1994) for a large sample of U.S. manufacturing firms. Our work is also related to Bond, Harhoff and Van Reenen (1999), who compare the cash flow sensitivity of British and German R\&D firms. They find that the cash flow sensitivity of fixed investment is positive and significant only for R\&D performing British firms. On the contrary, $R \& D$ is unaffected by cash flow in both countries.

To get further insights into the impact of restructuring on industry $R \& D$, we use our results to separate the impact on $R \& D$ through changing size distributions due to restructuring from the direct impact. In other words, we study how much of the change

\footnotetext{
${ }^{7}$ Arora and Gambardella (1998) have analyzed the causes of restructuring in some detail. They show that the restructuring began in the early 1980s in the US, but picked up momentum and spread to Western Europe by the late to mid 1980s, with Japan lagging behind.
} 
in the average R\&D intensity within industry segments is due to changes in scale distribution. We find restructuring to be an important component of the observed changes in $R \& D$ intensity. Moreover, the impact of restructuring differs across segments. For instance, in Life Sciences, most of the impact is through restructuring of firm portfolios rather than changes in the size distribution. In Other Chemicals, most of the impact is through changes in size distribution, with the size distribution becoming more equal after restructuring has had place. In Commodities, both matter, with an increase in size inequality as well as a direct increase in the inequality in R\&D due to restructuring of the firm portfolios. These results provide a new, more composite, perspective on the effect of corporate restructuring on $R \& D$.

\section{Data Description}

Our sample is based on the publicly traded North American, European and Japanese manufacturing firms included in Compustat's Global Vantage, a database which collects income and balance sheet information (including annual $R \& D$ expenditures) on thousands of firms worldwide. Among the manufacturing firms, we selected those with primary SIC in chemical and allied products (SIC 28), energy related (SIC 13,29,46), tires (SIC 3011), and other large and diversified companies with significant chemical related activities but primary SIC in different industries ${ }^{8}$. We further narrowed our selection by including only firms with at least one year of R\&D investment information for the years from 1987 to 1997 . The time frame chosen reflects a recent wave of intense restructuring in the industry as a whole. On the other hand, data are not available for the period before 1987 on a systematic basis. ${ }^{9}$ The resulting sample consists of 535 firms, of which about 58\% are North American companies, 21\% are Japanese, 13\% are European, and $8 \%$ are from the UK. Given that we only have R\&D data for a subset of the firm years, ours is an unbalanced panel.

We then identified the restructuring deals in which the selected firms where involved by linking Compustat's Global Vantage with restructuring data coming from the Security Data Company's (SDC) World-wide Mergers \& Acquisitions database, which covers almost 100,000 deals worldwide since 1985. SDC information for the U.S. is based on SEC filings ( $8 \mathrm{Ks}, 10 \mathrm{Ks}, 10 \mathrm{Qs}$ ), proxy statements, tender offers, annual reports, and for non-U.S. deals on over 200 English and foreign language news sources. We selected about 16,000 world-wide chemical related transactions, by including deals announced between 1987 and 1997 where the primary SIC of either the acquirer or the target company was chemical and allied products (SIC 28) or tire (SIC 3011) or oil \& gas \& petroleum refining (SIC 13,29,46). The 535 sample firms are responsible for about $30 \%$ of the selected worldwide chemical related deals.

\footnotetext{
${ }^{8}$ To select large chemical companies with non chemical primary sic we used the list provided by Aftalion (1989).

${ }^{9}$ Moreover, in the mid 1980s changes in accounting standards in some European countries, and the 1986 tax reform in the US suggest that comparing R\&D data to previous years may not be appropriate
} 
Each firm is assigned to one primary segment: Energy, Commodity Chemicals, Life Sciences, Other Chemicals, and Others. ${ }^{10}$ The Energy segment, related to oil extraction, is characterized by a low R\&D intensity, about $1 \%$, and the major research efforts consists of developing and improving process technologies. Many oil firms are now major chemical producers, particularly of basic petrochemical products such as ethylene and propylene, as well as a variety of industrial solvents. In the 1970s and 1980s, many of these firms further expanded into the production of a variety of plastics such as polyethylene and polypropylene.

Commodity Chemicals refers to chemicals produced in large quantities, and includes major inorganic chemicals such as fertilizers and soda, as well as organic chemicals such as solvents (e.g. pthalic anhydride), basic plastics (e.g. polyethylene) and fibers (e.g. polyester). Products in this segment are typically standard, their demand is highly price sensitive and cyclical, and the technology required for production, though sophisticated, is diffused widely. The average R\&D intensity in this segment is lowthe ratio of $R \& D$ over sales slightly varies around $3 \%$ during the 11 years analyzedalthough a few firms continue to make major investments in developing new processes and catalyst systems.

The Other Chemicals segment contains a variety of businesses and products, many of which tend to be differentiated and branded, such as adhesive, engineering plastics, and food additives and fine chemicals. Demand is relatively less price elastic than in Commodities or Energy, products are typically customized to the specific uses, and service and branding are an important source of competitive advantage for firms. ${ }^{11}$ Accordingly, research in this segment tends to focus on improving the properties of materials, and its R\&D intensity is about $3 \%$.

Life Science is the most research intensive segment, consisting mainly of pharmaceutical products, but also agricultural products such as seeds. The advent of recombinant DNA technology and molecular biology has opened up a number of opportunities for product and process innovation. This segment also has a substantial number of small but very research intensive firms, in contrast to the other segments where the smaller firms tend not to invest in research. The average ratio of R\&D over sales in our sample is about $9 \%$ at the beginning of the period analyzed and reaches about $11 \%$ in 1997 , showing a positive trend over time, differently from the other segments, whose $R \& D$ intensity is quite stable over time.

\footnotetext{
${ }^{10}$ Firms from the Compustat database have been grouped by segments accordin to their primary SIC code as assigned by Compustat. These are as follows: Energy corresponds to SIC 13,29,46; Commodity Chemiclas to SIC 281,282,286; Life Science to SIC 283; Other Chem to specialty (289) and agricultural chemicals (287), Soap, Cleaners, and Toilet Goods (284), and Paints and Allied Products (285); Others corresponds to other manufacturing SIC codes.

${ }^{11}$ However, this segment also contains a few products produced in smaller volumes with standard technology and price sensitive demand.
} 
Finally, we assign each company to one of four regions: North America (i.e. United States and Canada), Japan, United Kingdom, and Europe ${ }^{12}$. Tables 1 to 3 provide descriptive statistics for our sample. They show that nearly half of the observations come from deals involving U.S. or Canadian companies. Also, Japan is relatively underrepresented with respect to the size of its economy, and the share of transactions accruing to the UK is larger than that of Europe, if measured in terms of the economic size of their economies.

While the small number of Japanese deals is probably due to a reporting bias in the two databases we use, the relatively larger volume of U.S. and UK transactions is likely to reflect a genuine phenomenon. Table 2 also shows that there is some variation in the sectoral distribution of deals by region. For example, in the UK the deals in Commodity chemicals have been much less frequent than for Other chemicals or even Life Sciences, while the contrary is true for the U.S.. Table 3 documents the time pattern of R\&D intensity by segment. ${ }^{13}$

\section{R\&D and Corporate Restructuring}

The effects of restructuring can be studied at the level of the firm as well as the level of the industry. At the level of the firm the question is what does restructuring imply for firm $R \& D$, and in particular, whether restructuring reduces firm $R \& D$ as it is widely feared. At the level of the industry, we investigate what is happening to average $R \& D$ intensity and the distribution of in R\&D intensity across different segments within the industry.

\section{3(a) A Model of R\&D expenditure}

We assume that firms operate in many segments, each with a different level of R\&D intensity. Further, we assume that R\&D intensity may vary by scale. Thus we write:

$$
\mathrm{R}_{\mathrm{ij}}=\alpha_{\mathrm{j}} \mathrm{X}_{\mathrm{ij}}^{\beta}
$$

where: $\mathrm{R}=\mathrm{R} \& \mathrm{D}, \mathrm{X}=$ sales, $i=$ firm, and $j=$ industry segment. Note that $\beta$ is the scale parameter, showing the elasticity of $R \& D$ with respect to size, and $\alpha_{j}$ is a parameter that measures the R\&D intensity of the unit sized firm in segment $j$. For simplicity, we set the size of the median sized firm to unity, so that $\alpha_{j}$ measures the R\&D intensity of the

12 Nearly half of the Europen companies are from four countries: Germany (15\%), France (12\%), Switzerland (10\%), and Norway ( 9\%). The remaining companies are from the Netherlands, Italy, Belgium, Denmark, Finland, Sweden, Austria, and Ireland.

${ }^{13}$ Notice that, overall, R\&D intensity remains fairly constant in our sample. This contrasts with the often cited decline in intensity (also for the chemical industry) in NSF data. As first noticed by Hall (1990), NSF data come from a survey (which includes U.S> unlisted firms), while Compustat data derive from official accounting forms. Moreover, foreign firms listed in the U.S. are included in Compustat but not in NSF data, while R\&D performed abroad by U.S. firms is included in NSF but not in Compustat data. Hence the likely cause of the difference between NSF and our data. 
median firm in segment $\mathrm{j}$. We denote by $\mathrm{S}$ the revenue share of the $j$-th industry segment for firm $i$, and we write:

$$
R_{i}=\Sigma_{j} R_{i j}=\Sigma_{j} \alpha_{j} X_{i j}{ }^{\beta}=X_{i}^{\beta} \Sigma_{j} \alpha_{j} S_{i j}{ }^{\beta}
$$

Taking logs, letting lower case represent logged values, and using time subscripts, yields the following expression:

$$
\mathrm{r}_{\mathrm{it}}=\beta \mathrm{x}_{\mathrm{it}}+\log \left(\Sigma_{\mathrm{j}} \alpha_{\mathrm{jt}} \mathrm{S}_{\mathrm{ijt}}{ }^{\beta}\right)
$$

Note that the second term, which can be interpreted as the scale-adjusted R\&D intensity, is not observed. ${ }^{14}$ Further, it will vary across firms and within a firm, it will vary over time due to restructuring and to changes in segment level R\&D intensity.

This framework implies that restructuring affects R\&D in two ways: $(i)$ through a change in scale, and (ii) through a change in scale-adjusted R\&D intensity. In other words, R\&D may be affected both by changes in scale, measured by sales, and by segment specific shifts in scale-adjusted $R \& D$, i.e. $\alpha_{j}$ varies with time. Moreover, there could conceivably be firm-specific shifts in $R \& D$. We can allow for such firm-specific effects by specifying the $R \& D$ equation as:

$$
\mathrm{R}_{\mathrm{i}}=\mathrm{C}_{\mathrm{i}} \Sigma_{\mathrm{j}} \mathrm{R}_{\mathrm{ij}}=\mathrm{C}_{\mathrm{i}} \Sigma_{\mathrm{j}} \alpha_{\mathrm{j}} \mathrm{X}_{\mathrm{ij}}{ }^{\beta}=\mathrm{C}_{\mathrm{i}} \mathrm{X}_{\mathrm{i}}^{\beta} \Sigma_{\mathrm{j}} \alpha_{\mathrm{j}} \mathrm{S}_{\mathrm{ijt}}{ }^{\beta}
$$

where $C_{i}$ represents these firm specific effects. We face two basic problems in order to estimate equation (1) or (1a): (i) the unobservability of $S_{\mathrm{ijt}}$, and (ii) the non-linearity in the specification. A solution to the first problem comes from the fact that we can observe the number of acquisitions and divestitures, which represent a change in $S_{\mathrm{ijt}}$, but even here we face the problem that $S_{i j t}$ being a revenue share, $S_{i j t}$ increases with the number of (net) acquisitions and with the sales associated with each transaction, and it decreases with the existing scale of the firm (i.e. one acquisition will imply a bigger change in revenue shares for a smaller firm as it will for a larger firm). In order to tackle the non-linearity of (1), we write:

$$
\log \left(\Sigma_{\mathrm{j}} \alpha_{\mathrm{jt}} \mathrm{S}_{\mathrm{ijt}}{ }^{\beta}\right)=\mathrm{A}_{\mathrm{i}}+\mathrm{W}_{\mathrm{t}}+\mathrm{B}_{\mathrm{j}}+\Sigma_{\mathrm{j}} \gamma_{\mathrm{j}} \mathrm{Z}_{\mathrm{ijt}}
$$

where $A_{i}, W_{t}$, and $B_{j}$ are firm, time and industry segment specific effects, and $z_{i j t}$ represents the number of net acquisitions adjusted for scale in industry segment $j$ by firm $i$ at time $t$. This suggests an estimation strategy which relies on estimating an equation of the following type:

$$
\mathrm{r}_{\mathrm{it}}=\beta \mathrm{x}_{\mathrm{it}}+\mathrm{A}_{\mathrm{i}}+\mathrm{W}_{\mathrm{t}}+\mathrm{B}_{\mathrm{j}}+\Sigma_{\mathrm{j}} \gamma_{\mathrm{j}} \mathrm{z}_{\mathrm{ijt}}
$$

Here we assert that changes in $R \& D$ intensity across segments are common over time and captured by $\mathrm{W}_{\mathrm{t}}$, i.e. there are no time and segment specific effects, with possibly

\footnotetext{
${ }^{14}$ Only listed U.S. companies are required to report sales by major business line, but even here business lines may not fit with a technologically meaningful partition of the industry.
} 
different initial values (captured by $\mathrm{B}_{\mathrm{j}}$ ), and that the unobserved initial scale and composition effects are captured by $\mathrm{A}_{\mathrm{i}}$, which are unobserved firm-specific fixed effects. We implement this approach by estimating the following equation, which represents our preferred specification:

$\ln (\mathrm{R} \& \mathrm{D})_{\mathrm{it}}=\alpha+\beta \ln \left(\right.$ Sales $\left._{\mathrm{it}-1}\right)+\gamma_{1} \ln \left(\mathrm{CF}_{\mathrm{it}-1}\right)+\gamma_{2} \ln \left(\mathrm{LR}_{\mathrm{it}-1}\right)+\gamma_{3} \ln \left(\right.$ Debt $\left._{\mathrm{it}-1}\right)+\gamma_{4} \ln \left(\right.$ Equity $_{\mathrm{it}-}$ $\left.{ }_{1}\right)+\delta_{1} \operatorname{Aen}_{\mathrm{it}-1}+\delta_{2} \mathrm{Acn}_{\mathrm{it}-1}+\delta_{3} \mathrm{Aln}_{\mathrm{it}-1}+\delta_{4} \mathrm{Aotn}_{\mathrm{it}-1}+\alpha_{\mathrm{i}}+\eta_{\mathrm{t}}+\varepsilon_{\mathrm{it}}$

where:

- $R \& D$ represents all costs incurred during the year that relate to the development of new products or services;

- Sales represents gross sales reduced by cash discounts, trade discounts, and returned sales and allowances for which credit is given to customers; ${ }^{15}$

- $\quad C F=$ Cash Flow is defined as Income Before Extraordinary Items, i.e. a company's income after all expenses except provisions for dividends, to which depreciation and amortization charges are added;

- $\quad L R=$ Liquidity Ratio is the ratio of total current assets to total current liabilities. Total current assets represents cash and assets expected to be realized in cash and used in the production of revenue within next year. Total current liabilities represents debt and other liabilities due within one year;

- Debt is the sum of all corporate debts, irrespective of maturity;

- Equity represents total shareholders' equity;

- Aen represents net acquisitions (acquisitions net of divestitures) in energy related industries;

- Acn represents net acquisitions in commodity chemicals;

- Aln represents net acquisitions in life science industries;

- Aotn represents net acquisitions in other industries, chemical or not. ${ }^{16}$

We include four financial measures, cash flow, the liquidity ratio, debt, and equity. We do so because the literature on investment equations suggests that the most likely candidate for firm-specific effects in decisions on intangible investments are financial variables, to the extent that they reflect the severity of firm-specific financial constraints. We thus need to control for such effects when assessing how restructuring affects R\&D investment.

There are several reasons why firms may face credit constraints and may thus forego attractive investment opportunities, as argued in the large literature which developed

\footnotetext{
${ }^{15}$ We also estimated with current period sales, and with both current and lagged sales. The qualitative results are unchanged.

${ }^{16}$ Initially we had run our regressions using the two segments we use in the descriptive tables, namely 'other chemical' and 'other (non chemical)' industries. We have successively aggregated the two segments because of the excessively small number of transactions coded as 'other chemical' related. The reason is that restructuring deals are coded by Securities Data Company using the Venture Economics industry classification, which is much more detailed for high-technology than for other industries. As a result, many deals have a missing Venture Economics industry code that we recoded as 'other industries.' Although there exist also a SIC code associated with each SDC transaction, we preferred the Venture Economics coding for its advantages in distinguishing high-tech chemical industries. However, we checked the robustness of our results using the SIC classification.
} 
since the seminal work of Fazzari, Hubbard and Petersen (1988), and which is surveyed in Hubbard (1998) and Schiantarelli (1996).

Cash flow is relevant because it may shield a firm from the need to look for external finance. Hence we expect $\gamma_{1}$ to be positive. ${ }^{17}$ The liquidity ratio gives a measure of how a firm may use working capital to absorb possible credit crunches, given the high cost of changing the R\&D investment. Debt and equity reflect a firm's capital structure. We expect $\gamma_{3}$ to be negative since more debt absorbs cash flow to be serviced; on the contrary we expect $\gamma_{4}$ to be positive, since equity provides a more suitable form of financing for uncertain, long-term forms of investment like R\&D.

All the regressors are 1 year lagged. Given the relatively small $\mathrm{t}$ (11 years), we estimate $\eta_{t}$ by including a full set of year dummies in all the specifications. We estimate this specification with both random effects, where $\operatorname{Cov}\left(\alpha_{i}, x_{i t}\right)=0$, and fixed effects, where we make the hypothesis that $\operatorname{Cov}\left(\alpha_{i}, x_{i t}\right) \neq 0$. As we will see shortly, the random effect model is generally rejected, so that we base our main results using the fixed effect estimates.

The majority of our analysis is based on counts of transactions, acquisitions and divestitures. However, we have data on the reported value of the transaction for about $50 \%$ of the transactions. These data are not randomly distributed across firms and in particular, transactions involving European and Japanese are more likely not to have the value reported. Moreover, there are real concerns about the validity of the values accorded to the transactions, since these may not be assigned in a consistent way. Nonetheless, although we do not base ourselves on estimates involving values, we did estimate a specification using the value of net acquisitions.

We also tested a more general specification with acquisitions and divestitures included separately. Finally, we test a specification with total number of transactions to proxy for size. Total aggregate acquisitions and divestitures, when added to the segment level net restructuring measures as control for the level of restructuring activity, do not change results. The results of these specifications are consistent with our preferred specification.

POOLED SAMPLE DESCRIPTIVE STATISTICS (535 firms, 11 year period)

\begin{tabular}{lrrrrr}
\hline Variable & Mean & Stand. Dev. & Min & Max & Obs. \\
\hline & & & & & \\
R\&D $^{+}$ & 135 & 304 & 0 & 2,961 & 3,884 \\
Sales $^{+}$ & 4,150 & 10,436 & 0 & 128,207 & 4,370 \\
Cash flow $^{+}$ & 481 & 1,287 & $-1,855$ & 18,717 & 4,089 \\
Debt $^{+}$ & 1,274 & 5,875 & 0 & 162,406 & 4,372 \\
\hline
\end{tabular}

\footnotetext{
${ }^{17}$ It is common in the literature to control for investment opportunities using Tobin's q as a regressor, though this is a debated practice. This information is not available for European \& Japanese firms. We do attempt to control to some extent for segment specific opportunities by running within segment regressions. As well, since we use a firm fixed effect specification, we are not accounting for firm specific time varying opportunities.
} 


\begin{tabular}{lrrrrr}
\hline Equity $^{+}$ & 1,716 & 4,312 & $-1,563$ & 63,620 & 4,087 \\
Liquidity Ratio & 2.74 & 3.59 & 0.0002 & 57.26 & 4,347 \\
Net Acq. Energy & -0.029 & 0.466 & -10 & 5 & 5,885 \\
Net Acq. Commodity & 0.016 & 0.487 & -6 & 5 & 5,885 \\
Net Acq. Life Sc. & 0.031 & 0.446 & -4 & 5 & 5,885 \\
Net Acq. Other Ind. & 0.117 & 0.792 & -7 & 9 & 5,885 \\
\hline
\end{tabular}

Data for the 535 firms and the 11 years in the sample, $\left(^{+}\right)$indicates data in millions of US dollars. Net acquisitions are the number of transactions.

The above table provides descriptive statistics for our unbalanced panel. The average $\mathrm{R} \& \mathrm{D}$ expenditure is $\$ 135$ millions (median is $\$ 21$ millions), with $34 \%$ of the observations missing. About $\$ 4$ billions is the average sales in our sample (median is $\$ 800$ million). The sample firms have divested more than acquired, on average, energy related businesses (the number of net acquisitions in energy related industries is -0.03); whereas firms have acquired more than divested in other chemical and non chemical industries (the average number of net acquisitions in other industries is .12). Within the chemical industry firms have the largest number of net acquisitions in life sciences (0.03). The average number of acquisitions and divestitures in the sample-not reported in the table-is approximately 7 and 5, respectively. Note also that about $30 \%$ of the companies are inactive during the entire sample period.

\section{3(b) The impact of restructuring on firm-level $R \& D$}

We begin our econometric analysis by estimating (2). In Table 4 we report fixed effects regressions for the pooled sample. In Table 5 we report the same regression by segment, and in Table 6 by region. There are some noteworthy results which emerge from this analysis. Restructuring matters, with net acquisitions in different industries having an effect on $R \& D$, even controlling for size. If one looks at the pooled regression, we find that the estimated value of $\beta$ is 0.58 . The restructuring variables are as expected, with net acquisition in the two R\&D intensive segments-Life Sciences and Other Chemicals - having a positive and significant impact on R\&D, even after controlling for size, consistent with the interpretation in (2). The coefficients of the financial variables are all positive and, with the exception of debt, significant.

We performed our regression analysis using both the net number of acquisitions and the cumulative value (the latter not reported here), i.e. the number of acquisitions since 1987 to each year. On the whole the two specifications yield very similar qualitative results, with net acquisitions in Life Sciences, and to a lesser extent, Other Chemicals, increasing $R \& D$, particularly in less $R \& D$ intensive segments like commodities. In specifications using net cumulative acquisitions, the estimated elasticities had a similar range and tended to be slightly lower.

This pattern is consistent with the idea that the addition of a business to a firm's R\&D portfolio with $R \& D$ intensity higher than the average $R \& D$ intensity of the portfolio will increase the average $R \& D$ intensity of the portfolio. However, since an acquisition is likely to bring about scale changes, and since scale changes may affect R\&D differently 
in different segments-so that contrary to the maintained assumption, $\beta$ may differ across segments - the economic meaning of the coefficients of the net acquisition variables cannot be directly interpreted.

Using a Hausman specification test we reject the random effect model for the aggregate case and for the life science industry, but cannot reject it for the other business segment levels. At the regional level, the random effect is rejected for the US and Japan, but not for Europe and UK. For the US case, the random effect model is rejected for the Life Science industry and Other non chemical industries only. These tests suggest that there are both country and industry specificities affecting the relationships studied, suggesting to run the analysis both by segment and by region.

Notice that segment level estimates are potentially useful also because restructuring events may not be distributed randomly across firms. For instance, life science firms may be more likely to be involved in life science related acquisitions. They also partially control for differences in technical opportunity across segments.

By estimating (2) within industry segment, we allow the time effects to vary by industry segment and we also allow $\beta$ to vary by industry segment. The within industry segment specification is useful for another reason - it allows the coefficients on $\mathrm{z}_{\mathrm{ijt}}, \gamma_{\mathrm{j}}$ to vary by industry segment as well, which is desirable because the second term depends on $\beta$, and if $\beta$ varies by industry segment, so should the coefficients. Further, since the acquisition of a commodity unit by a pharmaceutical firm should have a different effect on scale adjusted R\&D intensity than the acquisition of the same unit by an energy firm, we should allow the coefficient of net acquisitions to vary by the industry segment of the restructuring firm. Clearly, the usefulness of this procedure depends on the accuracy of the classification of firms by industry segment.

There is considerable variation in the within industry segment estimates, in both the elasticity of R\&D with respect to scale and in the impact of restructuring. The estimated elasticity of R\&D with respect to sales varies between 0.27 (Commodities) and 0.74 (Other Chemicals). Variations is present even if we look at regional-level regressions: $\beta$ becomes small and insignificant for Japan, and larger than one (1.6), and significant, for Europe (and close to one for the UK) The segment-level estimates for North America are however very close to those for the whole sample.

Although our estimates may contain downward biases, we are confident that the elasticity is less than one because we find that at the level of the industry segment, mean $R \& D$ intensity and variance of $R \& D$ intensity tend to move in the same direction, as would be the case if $\beta$ were less than unity. We discuss this issue at greater length in section 3(d) below.

The significance of the net acquisition variables tends to be lower in the within industry segment estimates, although the qualitative patterns are similar, with net acquisitions in Life Sciences and Other Chemicals tending to increase R\&D. This drop in significance is an inevitable consequence of the reduced number of observations-recall that most of 
the key variables are identified by "within firm" variation over time, rather than variation across firms.

A strong assumption of the econometric framework thus far is that only net acquisitions matter, i.e., the coefficient on acquisition is equal and opposite in sign to that on divestiture. This is a testable proposition. The experiments on this are inconclusive, in part because the significance is often low, possibly because of multicollinearity. In some cases, the signs are unexpected, with divestitures increasing $R \& D$. One way to understand this is that acquisitions and divestitures are not random. Indeed, in some cases, acquisitions may be positively correlated with technological opportunities available to the firm in other segments, while in other cases divestitures may be negatively correlated.

To explore this further, we divided all firms into active and inactive with respect to their restructuring behavior. We define a firm as actively (inactively) restructuring if it had more (less) than the median number of transactions-which is three for the sample as a whole. Further, active firms were classified into net acquirers, net divestors and balanced. We then compared R\&D in two periods, 1990-91 and 1996-97 using two year averages by the industry segment. The results are shown in Table $7 .^{18}$ The first point to note is that active acquirers tend to be more R\&D intensive in most segments. Since active firms are unlikely to be the small firms (see Table 8), this implies that the higher $\mathrm{R} \& \mathrm{D}$ intensity is not due to scale effects but measures genuine differences in portfolio composition. Among active firms, acquirers are more R\&D intensive than divestors (and increasingly so over time) in Energy, Commodity and Other Chemicals, whereas the opposite is true for Life Sciences and Others. Another point to notice is that active divestors in Commodities see their R\&D intensity grow over time. There does not appear to be any clear trend in terms of changes in R\&D intensity over time for the sample as a whole. We investigate the change in $R \& D$ intensity distributions in more detail below.

Table 8, which shows the acquisitions and divestiture, by industry segment and by region, of the largest firms in each segment, suggest that restructuring is overall related to size, and also that firms active in restructuring tend to be more R\&D intensive. These figures do not throw any light on possible differences between acquirers and divestors, although they suggest that in $R \& D$ intensive industry segments, $R \& D$ intensive firms are more likely to be acquirers, while the reverse is true for the less $R \& D$ intensive segments.

We also find that financial variables do not affect the impact of restructuring on R\&D. In other words, whether we include financials or not in the specification, the coefficient of net acquisitions do not vary much, both in the pooled and in the segment level estimates. This is important, since it means that restructuring is not affecting $R \& D$ solely through its impact on the firm's financial position, for instance by increasing or decreasing liquidity or debt, as it may have appeared from the results of Bronwyn Hall.

\footnotetext{
18 The very high R\&D intensity for Life Science is due to the inclusion of a number of small biotechnology firms in the database. We will investigate excluding these firms in subsequent analysis.
} 
As far as the direct impact of financials on $R \& D$, at the aggregate level we find that all the financial variables have positive coefficients, although the elasticities are low. The coefficient estimates of debt and equity imply that a capital structure tilted towards debt restrains $\mathrm{R} \& \mathrm{D}$, as we would expect. However, also for financials we find wide variations across samples and specifications. The coefficient for cash flow, for example, ranges from 0.03 for Other Chemicals to 0.1 for Commodities, and is not significant for Life Sciences, which is not surprising. Interestingly, financial variables turn out not to be significant for Europe and only cash flow and liquidity matter for R\&D in Japan, two regions where the structure of the financial systems is often thought to be conducive to looser financial constraints. ${ }^{19}$

The foregoing specifications implicitly assume that $R \& D$ changes are a function only of past year restructuring. This assumption is questionable because $R \& D$ tends to be a long term investment. It is further questionable because theory suggests that the impact of restructuring should be long lived, and one-year-lagged sales may not adequately account for this. One way of modelling this is to think of $R \& D$ as adjusting over time to a restructuring event. The simplest model of that process implies that lagged R\&D is included as an explanatory variable.

It is current practice to estimate such specification in order to take care of adjustment costs and expectations about the future profitability of investments. In an exploratory exercise we then transformed the data into deviations from firm specific means (thus exploiting only within firm variation, as for the fixed effects model), and then used two year lagged values of $R \& D$ to instrument for 1 year lagged $R \& D$, using a two stage least square procedure. In unreported regression we obtain similar, albeit somewhat smaller values for $\beta$, which is 0.61 for the whole sample and ranges from 0.38 for Commodities and 0.65 for Life Sciences, and is always significant. The lower values of the segmentlevel estimates suggests that firms may not adjust their R\&D to annual changes in scale, but instead the adjustment period may be longer than one year, and that it may be particularly long for drugs but shorter for other industries. ${ }^{20}$

\section{3(c) The impact of restructuring on firm-level investment in tangible assets}

We also estimate a panel of North American companies to assess the impact of restructuring on tangible assets, using capital expenditure as dependent variable. Some studies do compare the behavior of tangible (capital) and intangible (R\&D) investment. For instance, using a panel of 581 firms in science-based industries, Hall, Mairesse, Branstetter, and Crepon (1999) find that cash flow is a good predictor of both capital investments and R\&D for the U.S., but not for France or Japan. Hall (1994) had also found that cash flow affects R\&D and capital investment in a similar fashion. Bond,

\footnotetext{
${ }^{19}$ Bond, Harhoff and Van Reenen (1999) specifically test the sensitivity of R\&D expenditure to financial constraints in Gernany and Britain, and find analogous results using a variety of specifications.

${ }^{20}$ Finally, we also estimate the main specification using the net value of the acquisitions. Results are still preliminary, but overall consistent with the results presented. The significance of the restructuring coefficients, however, drops, reflecting perhaps the loss of over $50 \%$ of the observations.
} 
Harhoff and Van Reenen (1999) find that capital expenditure does respond positively to cash-flow for British, but not for German R\&D performing firms, while R\&D is unaffected by cash flow in both countries. These results are consistent with the view that the dependence of investment on cash flow varies with the nature of (national) financial system.

We check whether there is a difference in the effect of restructuring on these two types of investment for different segments of the chemical industry. To do so, we estimate both (2) and (3) with capital investments (i.e. capital expenditure) as the dependent variable. We report our results for North America in Table 9. There are some intriguing insights we gain from this exercise. First, financial variables play a larger role for capital investments than for R\&D investment-their coefficients are larger and more often significant than for $R \& D$. This result is fairly stable across samples (it is confirmed in unreported segment- and regional-level regressions), and suggests that $R \& D$ and capital investments constitute different types of investment. Surprisingly, measures of restructuring seems not to yield any effect on capital investments, whatever sample or specification we use.

We also notice that capital expenditure is consistently less responsive to sales than R\&D across specifications and samples. This effect is similar for the sales and restructuring coefficients, suggesting that the impact we are measuring is at least in part genuinely due to business portfolio composition effects, as businesses in different industry segments vary in both $\mathrm{R} \& \mathrm{D}$ and capital investments intensity. Moreover, whereas adding the lagged dependent variable has a large impact on the estimates of scale for $\mathrm{R} \& \mathrm{D}$, it hardly hs an effect on those estimates for capital investments.

This result is consistent with the idea that whereas investments in tangible capital can be made on a year to year basis, those in intangible capital tend to be slower and more cumulative. Put differently, building an $R \& D$ program requires investments over many years and cannot be rushed beyond a point. The result is that $R \& D$ spending, which to a large extent corresponds to the hiring of human capital, tends to be much smoother than spending on physical capital. Morevoer, our result suggests that taking into account differences across segments in terms of R\&D and capital intensity helps understanding that restructuring affects them also by shifts in the firm-, segment-, and industry-level portfolios of businesses.

\section{3.(d) The impact of restructuring on industry-level R\&D}

A different set of questions relates to the effect of restructuring on industry. In other words, the question is related to what forces drive or characterize the restructuring. There are a variety of conjectures in this regard. A prominent conjecture is that restructuring is marked by an increase in firm focus. What would this mean at the industry level? An increase in firm focus may make firms more similar to each other in terms of R\&D intensity, if they focus on similar businesses. Alternatively, restructuring may push firms in different directions, with some firms increasing their share of R\&D intensive businesses and others decreasing their share. 
Indeed, both types of effects may be seen in different segments. Arora and Gambardella (1998) claim that diversified firms, typically classified as commodity chemicals, are divesting the low R\&D businesses and purchasing specialty and other R\&D intensive businesses. However, other commodity chemical firms, such as Quantum chemicals, Cain Chemicals, or Huntsman, that are purchasing the divested unites, have adopted a different model that relies on cutting R\&D and maximizing cost efficiencies. In other words, in commodity chemicals and energy, we would expect firms to diverge from each other in terms of R\&D intensity.

On the other hand, in Life Sciences, Arora and Gambardella (1998) report that firms are being forced to divest the low $\mathrm{R} \& \mathrm{D}$ businesses, which tend to be acquired almost exclusively by non-Life Science firms. This would suggest that in Life Sciences, firms would tend to become more similar in their R\&D. The situation is less clear cut for Other Chemicals, since either trend could dominate.

The scale dependence of $R \& D$ further complicates the analysis. Assuming that $\beta$ is less than one, an across-the-board increase in size will increase $R \& D$ but reduce $R \& D$ intensity, holding other things constant. Suppose indeed we hold the composition of business portfolios and average size constant. Then an increase in size inequality-i.e. a 'mean preserving' spread which shifts more probability mass towards very large and very small firms - will reduce expected $R \& D$. Conversely, a more equal distribution of size will increase expected $R \& D$. This follows because $R \& D=R D=\alpha X^{\beta}$, which is a concave function of size. Note that the variance of RD is given by $\Sigma_{\mathrm{x}}\left(\alpha^{2} \mathrm{X}^{2 \beta} \mathrm{f}(\mathrm{X})\right)-$ $\left[\Sigma_{\mathrm{x}}\left(\alpha \mathrm{X}^{\beta} \mathrm{f}(\mathrm{X})\right)\right]^{2}$. Since $\alpha^{2} \mathrm{X}^{2 \beta}$ is a convex function, an increase in inequality in the distribution will increase its expected value while $\alpha X^{\beta}$ will decrease in expected value. Thus, holding scale, portfolio composition, and $\beta$ constant, an increase in size inequality will reduce overall $R \& D$, increase $R \& D$ intensity and increase the variance of both $\mathrm{R} \& \mathrm{D}$ and $\mathrm{R} \& \mathrm{D}$ intensity.

In order to observe the impact of restructuring on firm focus, we need to adjust for changes in the size distribution of firms, which may also be due to restructuring. To do so, we construct 'predicted R\&D intensities' using the estimated values of $\beta$ from the within industry segment regressions, and scale the predicted values so that the average of the predicted $R \& D$ intensity is the same as the actual $R \& D$ intensity. Let estimated $\mathrm{R} \& \mathrm{D}$ for firm $i$ in time $t$ be $\mathrm{RD}_{\mathrm{ti}}=\lambda_{\mathrm{t}} \mathrm{RD}_{0 \mathrm{i}}\left(\mathrm{X}_{\mathrm{ti}}{ }^{\beta} / \mathrm{X}_{0 \mathrm{i}}{ }^{\beta}\right)$, where we use time period zero as the baseline and $\lambda_{\mathrm{t}}$ is chosen such that $\Sigma_{\mathrm{i}} \mathrm{RD}_{\mathrm{ti}}=\Sigma_{\mathrm{i}} \mathrm{R}_{\mathrm{ti}}$, where $\mathrm{R}_{\mathrm{it}}$ is actual $\mathrm{R} \& \mathrm{D}$ for firm $i$ at time $t$. This allows us to get an estimated distribution of $\mathrm{R} \& \mathrm{D}$ which adjusts for scale and for size distribution. Note that adjusting in this way assumes that the restructuring of portfolios does not have any impact on average R\&D intensity. Put differently, we are assuming that any change in average R\&D intensity, once we control for the firm size distribution, is due entirely to exogenous time shifts in the average.

We have done these comparisons for Commodities, Life Sciences and Other Chemicals, since these are the three chemical segments-Energy and Others are not such, though chemical firms own businesses there. As the base time period we use 1990 and 1991. 
We use two years to minimize the problem due to missing values and take average values for firms for which data are available for both years. Likewise, we use 1996 and 1997 as the comparison period. For each industry segment, we show in Figure 1 three cumulative density plots: for 1990-91, for 1996-97, and the predicted cumulative density.

Table 10 provides the means and standard deviations. Note that consistent with our finding that $\beta$ is less than one, average $R \& D$ intensity and its standard deviation move together. In Commodities, there is a small increase in R\&D intensity, as well as an increase in its standard deviation, with a marked increase in the coefficient of variation. As Figure 1(a) also shows, the predicted curve lies below the 1990-91 curve suggesting that the increased inequality in size alone would have caused the increased R\&D intensity.

The picture is quite different for Life Sciences. We observe a small decrease in average R\&D intensity, along with a decrease in its standard deviation. As we have already pointed out, this industry segment contains a number of very small research oriented firms. Even after applying a size cutoff ( $\$ 10$ million in sales), we still have firms with very high research intensities, which confirms the research-dependence of this segment. Over time, many of these firms have grown, with a corresponding decrease in research intensity, which may account for the measured decrease in the average research intensity (note well that this is a simple average, not weighted by firm size.) In any event, as can be readily seen in Figure 1(b), the predicted $R \& D$ intensity cumulative curve lies between the actual ones in the central values of the distribution, and below the 1996-97 elsewhere. Therefore, the decline in standard deviation is almost entirely due to the restructuring, rather than to changes in the size distribution.

In Other Chemicals, which includes specialty chemicals and other R\&D intensive segments of the chemical industry, there is a decrease in average R\&D intensity, along with a substantial decrease in standard deviation. However, most of the decrease in the standard deviation of $R \& D$ intensity is due to greater equality in size, with relatively little impact of portfolio restructuring-Figure 1(c) shows the predicted RDI curve to lie over the actual 1997-97 curve.

Overall, then, we find evidence that restructuring, defined as a change in the composition of firms' business portfolio, is behind the changes in R\&D intensity which have characterized the chemical industry over the period under consideration. Notice also that the mean and standard deviation of $R \& D$ intensity tend to move together, consistent with the idea that R\&D intensity is decreasing in firm size. Further, the impact of restructuring differs across segments. In Life Sciences, most of the impact is through restructuring of firm portfolios rather than changes in the size distribution. In Other Chemicals, most of the impact is through changes in size distribution, with the size distribution becoming more equal. In Commodities, both matter, with an increase in size inequality as well as a direct increase in the inequality in $R \& D$ due to restructuring of the firm portfolios. 


\section{Conclusions}

We provide a new perspective on the economics of restructuring and R\&D. To the best of our knowledge, our study is the first to explore firm-level data for an analysis of the effects of restructuring on $\mathrm{R} \& \mathrm{D}$ using data on both acquisitions and divestitures, and a panel composed of a large number of chemical companies from many countries.

We focus on a single industry, which has undergone a long period of thorough restructuring, and for which we are able to identify technologically homogeneous segments. We find that restructuring matters for $\mathrm{R} \& \mathrm{D}$, and that (net) acquisitions of businesses in research-intesive segments have the highest effect. The considerable variation in segment-level estimates documents the different nature of the dependence of $R \& D$ on restructuring across industry segments. For instance, we find that the elasticity of $\mathrm{R} \& \mathrm{D}$ with respect to sales is less than one, but varies widely across industry segments.

We also find that financial variables, while affecting $R \& D$ as already known, do not affect the way restructuring affects $R \& D$, a result of interest in itself. We also separate the variation in $R \& D$ intensity which comes from changes in scale from that which comes from changes in the composition of a firm's portfolio of businesses. We find that both effects matter, but differently in different industry segments. Overall, the new evidence we uncover provide a new perspective on the effects of corporate restructuring on R\&D. 


\section{References}

Aftalion, Fred (1989), History of the International Chemical Industry, Philadelphia, University of Pennsylvania Press.

Arora, Ashish, and Alfonso Gambardella (1998) 'Evolution of Industry Structure in the Chemical Industry,' in Ashish Arora, Ralph Landau, and Nathan Rosenberg (eds), Chemicals and Long-term Growth, New York, Wiley \& Sons.

Arora, Ashish, Ralph Landau, and Nathan Rosenberg, (eds.) (1998), Chemicals and Long-term Economic Growth, New York, John Wiley \& Sons.

Blair, Margaret, and Robert Litan (1990), "Corporate Leverage and Leveraged Buy-Outs in the Eighties," in John Shoven and Joel Waldfogel (eds.) Debt, Taxes, and Corporate Restructuring, Washington, DC, Brookings Institution, p.43-80.

Blair, Margaret and Martha Schary (1993) 'Industry-level Pressures to Restructure,' in Margaret Blair (ed.) The Deal Decade, Washington, D.C., The Brookings Institution.

Bond, Steven, Dietmar Harhoff, and John Van Reenen (1999) 'Investment, R\&D and Financial Constraints in Britain and Germany,' Institute of Fiscal Studies Working Paper 99-05.

Chandler, Alfred (1990), "Scale and Scope: the Dynamics of Industrial Capitalism," Cambridge, Harvard University Press.

Cohen, W.M., (1995), "Empirical Studies of Innovative Activity," in Paul Stoneman, ed., Handbook of the Economics of Innovation and Technological Change, Oxford, Basil Blackwell.

Fazzari, Steven, Hubbard, Robert and Bruce Petersen (1988), 'Financing Constraints and Corporate Investment,' Brooking Papers on Economic Activity: Microeconomics, Washington D.C., The Brookings Institution, p.141-95.

Fusfeld, Herbert (1987), 'Corporate Restructuing-what impact on U.S. industrial research?' Research Management, v.30 (July-AUgust), p.10-17.

Hall, Bronwyn (1988) "The Effect of Takeover Activity on Corporate Research and Development," in Alar Auerbach (ed.) Corporate Takeovers: Causes and Consequences, Chicago, University of Chicago Press, 69-96.

Hall, Bronwyn (1990) "The Impact of Corporate Restructuring on Industrial Research and Development," in Brookings Papers on Economic Activity: Microeconomics, Washington D.C., The Brookings Institution, p.85-135.

Hall, Bronwyn (1992) "Investment and R\&D at the Firm Level: Does the Source of Financing Matter?” NBER Working Paper 4096. 
Hall, Bronwyn (1994) "Corporate Restructuring and Investment Horizon in the United States, 1976-1987,” Business History Review, Spring 1994, p.110-43.

Hall, Bronwyn (1999), "Mergers and R\&D Revisited," mimeo, University of California at Berkeley.

Hall, Bronwyn, Jaques Mairesse, Leo Branstetter and Bruno Crepon (1999) "Does Cash Flow Cause Investment and R\&D? An Exploration Using Panel Data for French, Japanese and United States Scientific Firms," in David Audretsch and A.R. Thurik (eds.) Innovation, Industry Evolution and Employment, Cambridge, Cambridge University Press.

Hubbard, Robert (1998) 'Capital-Market Imperfections and Investment,' Journal of Economic Literature, v.36, p.193-225.

Kaplan, Stephen (1989) "The Effects of Management Buyouts on Operating Performance and Value," Journal of Financial Economics, v.24, p.217-54.

Lichtenberg, Frank, and Donald Siegel (1990) "The Effects of Leveraged Buyouts on Productivity and Related Aspects of Firm Behavior," Journal of Financial Economics, v.27, p.165-94.

Miller, Robert (1990), 'Do Mergers and Acquisitions Hurt R\&D?' Research Management, v.33 (March-April), p.11-15.

Schiantarelli, Fabio (1996), 'Financial Constraints and Investment: A Critical Survey of International Evidence,' Oxford Review of Economic Policy, v.12.

Smith, Abbie (1990), "Corporate Ownership Structure and Performance: The Case of Management Buyouts, ” Journal of Financial Economics, v.27, p.127-64.

Stein, Jeremy (1988) "Takeover Threats and Managerial Myopia," Journal of Political Economy, v.96, p.61-80.

Tirole, Jean (1988), The Theory of Industrial Organization, Cambridge, MA, The MIT Press. 


\section{Tables}

Table 1 : Restructuring volumes and value, by region

\begin{tabular}{l|rrr|rrr}
\hline \multicolumn{3}{c}{ Acquisitions } & \multicolumn{3}{c}{ Divestitures } \\
\hline Region & Number & $\begin{array}{c}\text { Average value } \\
(\$ \mathrm{~m})\end{array}$ & $\begin{array}{c}\text { Observations } \\
\text { with value }(\%)\end{array}$ & $\begin{array}{c}\text { Number } \\
\begin{array}{c}\text { Average value } \\
(\$ \mathrm{~m})\end{array}\end{array}$ & $\begin{array}{c}\text { Observations } \\
\text { with value (\%) }\end{array}$ \\
\hline & & & & & & \\
NA & 1,635 & 8.47 & $43 \%$ & 776 & 9.45 & $55 \%$ \\
Japan & 155 & 1.48 & $46 \%$ & 13 & 0.21 & $39 \%$ \\
EU & 903 & 26.99 & $32 \%$ & 178 & 16.94 & $32 \%$ \\
UK & 609 & 17.07 & $62 \%$ & 241 & 12.89 & $53 \%$ \\
& & & & & & \\
\hline
\end{tabular}

Table 2 : Restructuring volumes, by segment and region

\begin{tabular}{|c|c|c|c|c|c|c|c|c|c|c|c|}
\hline \multirow[b]{2}{*}{ Segment } & \multirow[t]{2}{*}{ Region } & \multirow[t]{2}{*}{ NA } & \multicolumn{3}{|c|}{ Japan } & \multirow[t]{2}{*}{ EU } & \multicolumn{3}{|c|}{ UK } & \multicolumn{2}{|l|}{ TOT } \\
\hline & & & $\%$ & & $\%$ & & $\%$ & & $\%$ & & $\%$ \\
\hline \multirow[t]{2}{*}{ ENERGY } & Acquisitions & 326 & $58 \%$ & 5 & $0.9 \%$ & 148 & $26 \%$ & 82 & $15 \%$ & 561 & $100 \%$ \\
\hline & Divestitures & 434 & $61 \%$ & 2 & $0.3 \%$ & 158 & $22 \%$ & 114 & $16 \%$ & 708 & $100 \%$ \\
\hline \multirow[t]{2}{*}{ COMMODITY } & Acquisitions & 351 & $61 \%$ & 42 & $7 \%$ & 132 & $23 \%$ & 47 & $8 \%$ & 572 & $100 \%$ \\
\hline & Divestitures & 277 & $78 \%$ & 4 & $1 \%$ & 60 & $17 \%$ & 15 & $4 \%$ & 356 & $100 \%$ \\
\hline \multirow[t]{2}{*}{ LIFE SCIENCE } & Acquisitions & 362 & $49 \%$ & 40 & $5 \%$ & 233 & $31 \%$ & 109 & $15 \%$ & 744 & $100 \%$ \\
\hline & Divestitures & 225 & $51 \%$ & 15 & $3 \%$ & 118 & $27 \%$ & 84 & $19 \%$ & 442 & $100 \%$ \\
\hline OTHER & Acquisitions & 509 & $45 \%$ & 66 & $6 \%$ & 277 & $25 \%$ & 274 & $24 \%$ & 1,126 & $100 \%$ \\
\hline CHEMICAL & Divestitures & 326 & $51 \%$ & 13 & $2 \%$ & 121 & $19 \%$ & 176 & $28 \%$ & 636 & $100 \%$ \\
\hline \multirow[t]{2}{*}{ OTHERS } & Acquisitions & 250 & $40 \%$ & 13 & $2 \%$ & 177 & $29 \%$ & 180 & $29 \%$ & 620 & $100 \%$ \\
\hline & Divestitures & 188 & $46 \%$ & & $0.2 \%$ & 127 & $31.3 \%$ & 90 & $22 \%$ & 406 & $100 \%$ \\
\hline \multirow[t]{2}{*}{ TOTAL } & Acquisitions & 1,798 & $49.9 \%$ & 166 & $4.6 \%$ & 967 & $26.7 \%$ & 692 & $19.1 \%$ & 3,623 & $100.0 \%$ \\
\hline & Divestitures & 1,450 & $56.9 \%$ & 35 & $1.4 \%$ & 584 & $22.9 \%$ & 479 & $18.8 \%$ & 2,548 & $100.0 \%$ \\
\hline
\end{tabular}

Table 3a : R\&D intensity and N. of firms with $R \& D$ data, by segment and year 


\begin{tabular}{lrrrrrrrrrrrr}
\hline & \multicolumn{3}{c}{1987} & \multicolumn{2}{c}{1988} & \multicolumn{3}{c}{1989} & \multicolumn{3}{c}{1990} & \multicolumn{3}{c}{1991} & \multicolumn{3}{r}{1992} \\
& RDI & $\mathrm{N}$ & RDI & $\mathrm{N}$ & RDI & $\mathrm{N}$ & RDI & $\mathrm{N}$ & RDI & $\mathrm{N}$ & RDI & $\mathrm{N}$ \\
\hline ENERGY & $0.7 \%$ & 35 & $0.7 \%$ & 36 & $0.8 \%$ & 42 & $0.8 \%$ & 42 & $0.9 \%$ & 42 & $0.9 \%$ & 42 \\
COMMODITY & $3.1 \%$ & 34 & $3.1 \%$ & 45 & $3.3 \%$ & 54 & $3.4 \%$ & 58 & $3.5 \%$ & 61 & $3.6 \%$ & 64 \\
LIFE SCIENCE & $8.8 \%$ & 79 & $9.0 \%$ & 101 & $8.6 \%$ & 116 & $8.6 \%$ & 118 & $9.0 \%$ & 119 & $9.6 \%$ & 120 \\
OTHER CHEMICAL & $3.7 \%$ & 60 & $3.5 \%$ & 65 & $3.8 \%$ & 81 & $3.9 \%$ & 83 & $3.9 \%$ & 89 & $4.1 \%$ & 90 \\
OTHERS & $3.5 \%$ & 27 & $3.1 \%$ & 31 & $3.0 \%$ & 40 & $3.5 \%$ & 41 & $3.7 \%$ & 41 & $3.8 \%$ & 43 \\
\hline Total & $2.6 \%$ & 235 & $2.8 \%$ & 278 & $2.9 \%$ & 333 & $2.9 \%$ & 342 & $3.2 \%$ & 352 & $3.5 \%$ & 359 \\
\hline
\end{tabular}

\begin{tabular}{lrrrrrrrrrr}
\hline & \multicolumn{3}{c}{1993} & \multicolumn{2}{c}{1994} & \multicolumn{2}{c}{1995} & \multicolumn{2}{c}{1996} & 1997 \\
& RDI & $\mathrm{N}$ & RDI & $\mathrm{N}$ & RDI & $\mathrm{N}$ & RDI & $\mathrm{N}$ & RDI & $\mathrm{N}$ \\
\hline ENERGY & $0.9 \%$ & 46 & $0.8 \%$ & 45 & $0.7 \%$ & 48 & $0.6 \%$ & 42 & $0.7 \%$ & 39 \\
COMMODITY & $3.8 \%$ & 66 & $3.5 \%$ & 63 & $3.1 \%$ & 79 & $3.1 \%$ & 82 & $3.8 \%$ & 71 \\
LIFE SCIENCE & $10.1 \%$ & 121 & $9.8 \%$ & 124 & $10.4 \%$ & 143 & $10.9 \%$ & 141 & $11.0 \%$ & 113 \\
OTHER CHEMICAL & $4.0 \%$ & 93 & $3.6 \%$ & 91 & $3.2 \%$ & 106 & $3.2 \%$ & 109 & $3.2 \%$ & 93 \\
OTHERS & $3.5 \%$ & 44 & $3.4 \%$ & 44 & $3.1 \%$ & 45 & $2.9 \%$ & 45 & $3.1 \%$ & 42 \\
\hline Total & $3.6 \%$ & 370 & $3.6 \%$ & 367 & $3.4 \%$ & 421 & $3.4 \%$ & 419 & $3.3 \%$ & 358 \\
\hline
\end{tabular}

Table 3b : Average R\&D intensity 1987-‘97, by segment and region

\begin{tabular}{lrrrrr}
\hline & NA & Japan & EU & UK & Total \\
\hline ENERGY & $0.7 \%$ & $0.6 \%$ & $0.9 \%$ & $0.7 \%$ & $0.8 \%$ \\
COMMODITY & $3.3 \%$ & $3.3 \%$ & $3.5 \%$ & $2.3 \%$ & $3.3 \%$ \\
LIFE SCIENCE & $13.1 \%$ & $9.4 \%$ & $8.7 \%$ & $9.0 \%$ & $10.7 \%$ \\
OTHER CHEMICAL & $3.3 \%$ & $3.6 \%$ & $3.4 \%$ & $2.5 \%$ & $3.3 \%$ \\
OTHERS & $3.2 \%$ & $2.8 \%$ & $3.6 \%$ & $1.4 \%$ & $3.0 \%$ \\
\hline Total & $3.3 \%$ & $4.0 \%$ & $3.1 \%$ & $2.7 \%$ & $3.2 \%$ \\
\hline
\end{tabular}

Table 4 : Fixed effects regressions for the pooled sample

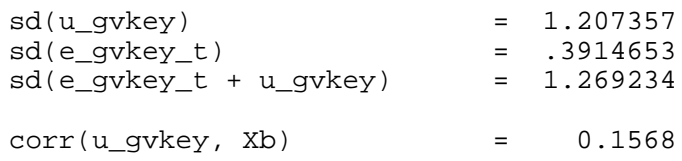

\begin{tabular}{|c|c|c|c|c|c|c|}
\hline $\operatorname{lrd}$ & Coef. & Std. Err. & $t$ & $P>|t|$ & [95\% Conf. & Interval] \\
\hline lsales1 & .5810154 & .0512516 & 11.337 & 0.000 & .4805031 & .6815276 \\
\hline $\operatorname{lcfl} 1$ & .0362119 & .019998 & 1.811 & 0.070 & -.0030073 & .075431 \\
\hline lliquidl & .0501257 & .0395842 & 1.266 & 0.206 & -.027505 & .1277563 \\
\hline $1 d t 1$ & .0248889 & .0133014 & 1.871 & 0.061 & -.001197 & .0509749 \\
\hline leq1 & .1579396 & .035621 & 4.434 & 0.000 & .0880814 & .2277978 \\
\hline $\operatorname{acn} 1$ & .0101704 & .0138968 & 0.732 & 0.464 & -.0170834 & .0374242 \\
\hline aen1 & .0048644 & .0146164 & 0.333 & 0.739 & -.0238007 & .0335295 \\
\hline $\operatorname{aln} 1$ & .0434744 & .0164433 & 2.644 & 0.008 & .0112267 & .0757222 \\
\hline $\operatorname{aotn} 1$ & .0133142 & .0097571 & 1.365 & 0.173 & -.005821 & .0324494 \\
\hline
\end{tabular}


Table 5 : Fixed effects regressions, by industry segment

\section{5a) Energy}

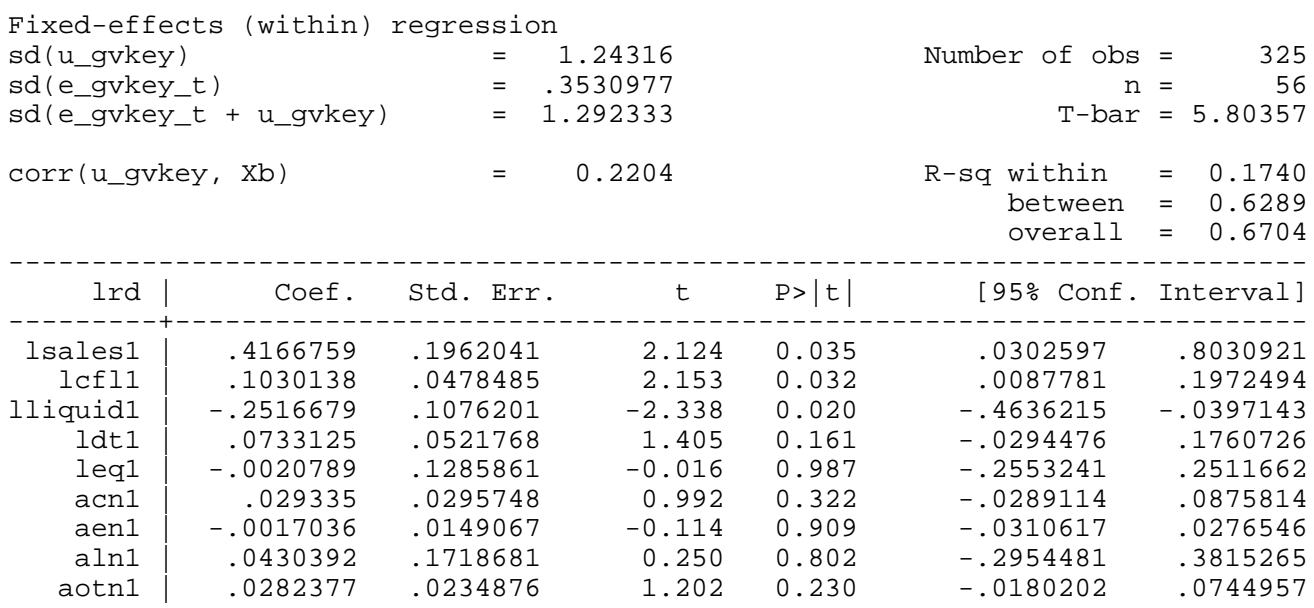

\section{5b) Commodity chemicals}

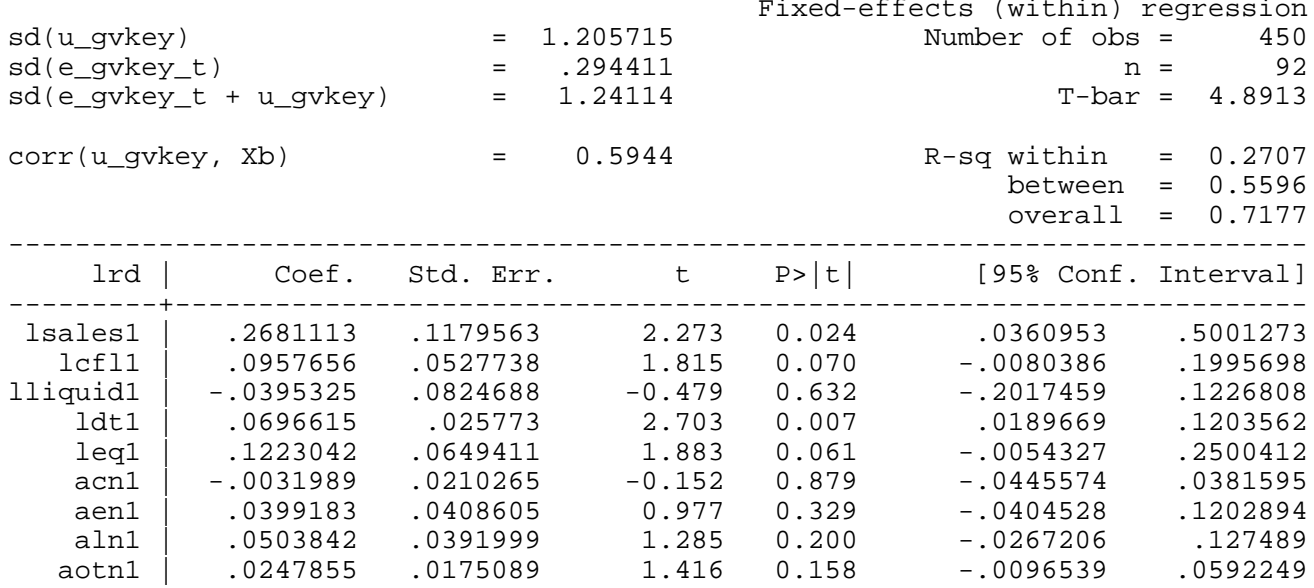

\section{5c) Life Sciences}

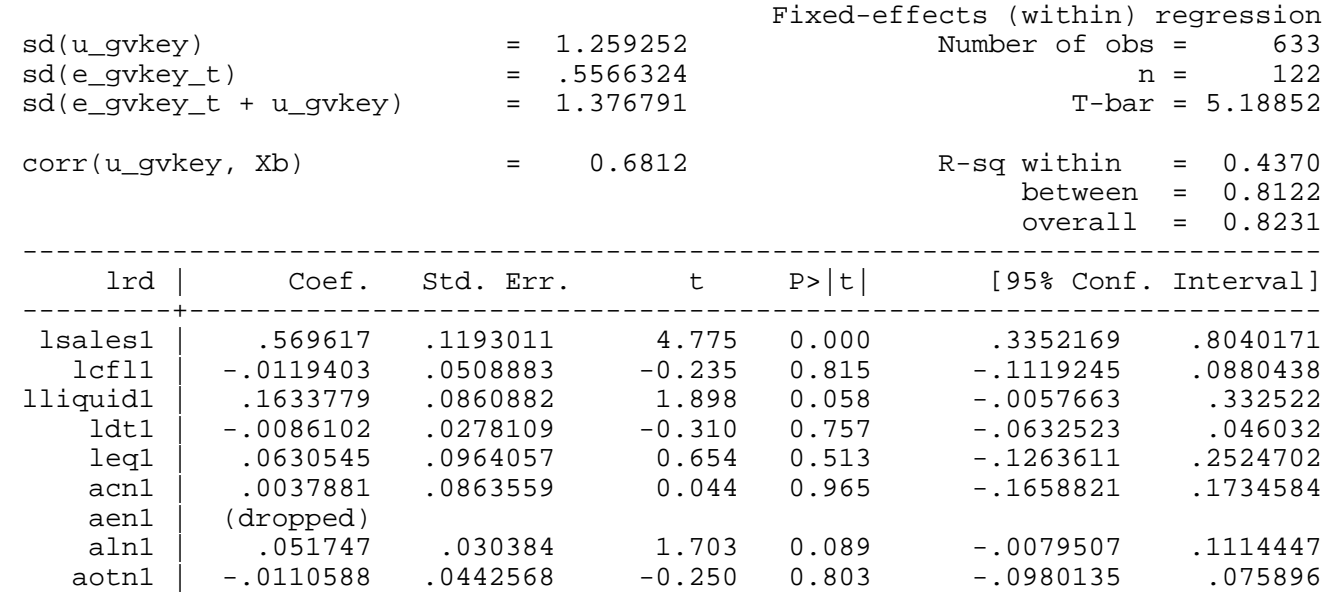




\section{5d) Other chemicals}

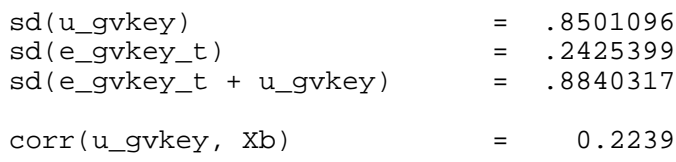

Fixed-effects (within) regression Number of obs $=\quad 719$

$$
\begin{array}{rr}
\mathrm{n}= & 121 \\
\mathrm{~T}-\mathrm{bar} & =5.94215
\end{array}
$$

R-sq within $=0.5061$ between $=0.8073$ overall $=0.8476$

\begin{tabular}{|c|c|c|c|c|c|c|}
\hline $\operatorname{lrd}$ & Coef. & Std. Err. & t & $P>|t|$ & [95\% Conf. & Interval] \\
\hline lsales1 & .7433433 & .0693293 & 10.722 & 0.000 & .6071762 & .8795104 \\
\hline lcfl1 & .0368309 & .0234331 & 1.572 & 0.117 & -.0091932 & .0828551 \\
\hline lliquid1 & .0736663 & .0624652 & 1.179 & 0.239 & -.0490193 & .1963519 \\
\hline $1 d t 1$ & .0423858 & .0170396 & 2.487 & 0.013 & .0089189 & .0758526 \\
\hline leq1 & .145811 & .0428463 & 3.403 & 0.001 & .0616582 & .2299639 \\
\hline $\operatorname{acn} 1$ & .0002318 & .014226 & 0.016 & 0.987 & -.0277089 & .0281726 \\
\hline aen1 & .0402972 & .0631877 & 0.638 & 0.524 & -.0838074 & .1644018 \\
\hline $\operatorname{aln} 1$ & .025175 & .0270265 & 0.931 & 0.352 & -.0279068 & .0782568 \\
\hline $\operatorname{aotn} 1$ & .0135758 & .0098984 & 1.372 & 0.171 & -.0058651 & .0330168 \\
\hline
\end{tabular}

\section{5e) Others}

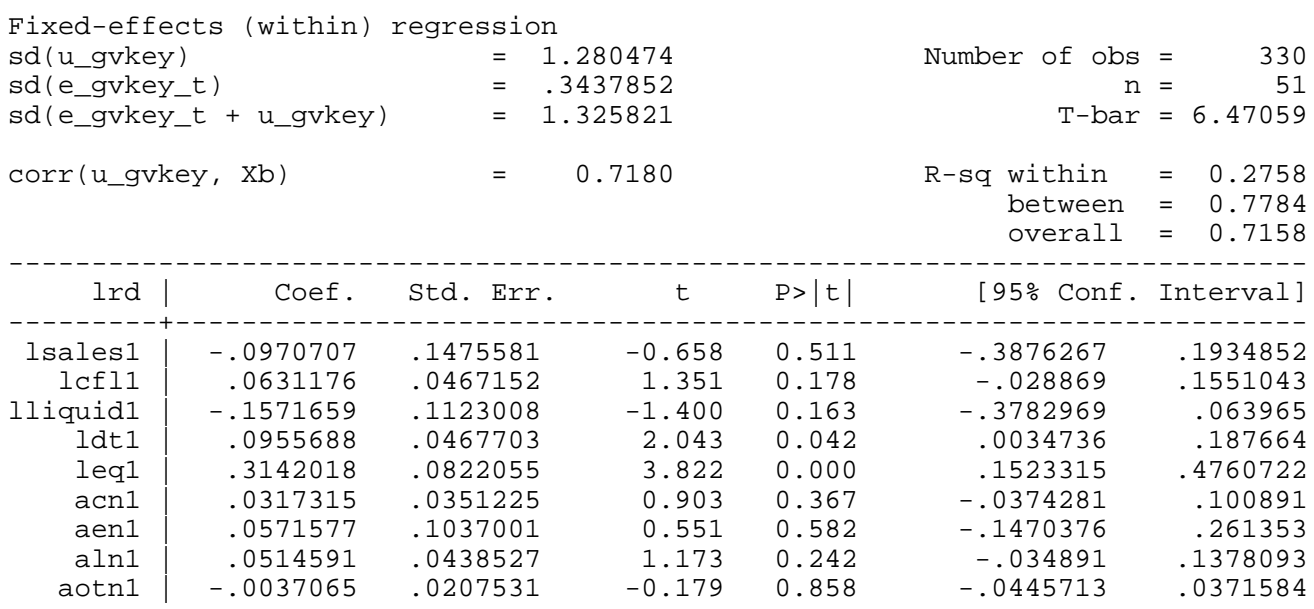

\section{Table 6 : Fixed effects regressions, by region}

\section{6a) North America}

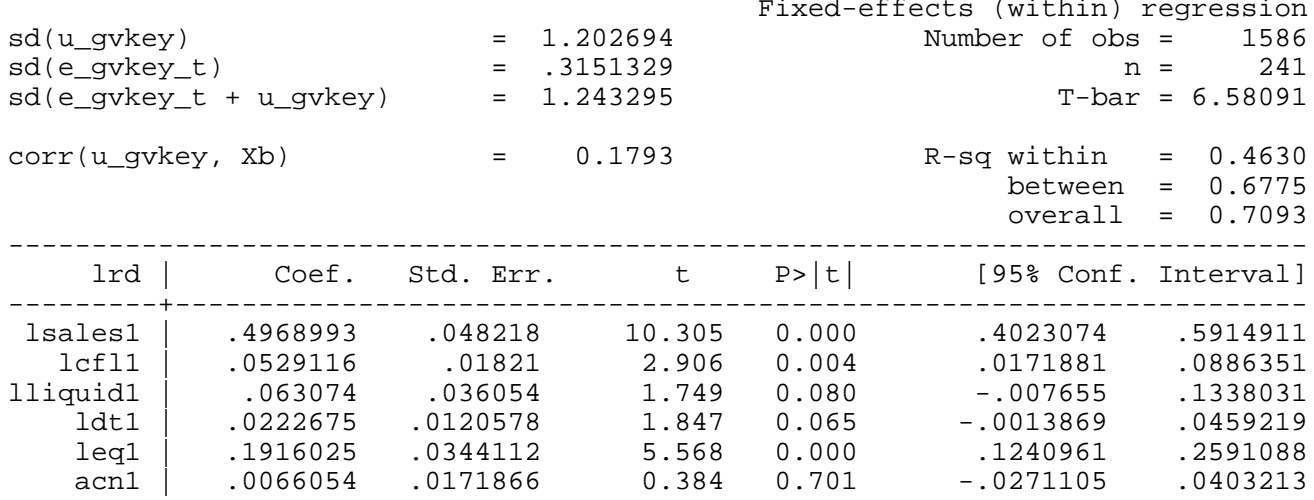




\begin{tabular}{r|rrrrrr} 
aen1 & .0185595 & .014451 & 1.284 & 0.199 & -.0097898 & .0469087 \\
$\operatorname{aln} 1$ & .0509231 & .0189866 & 2.682 & 0.007 & .0136761 & .0881702 \\
aotn1 & .0170295 & .0104397 & 1.631 & 0.103 & -.0034506 & .0375097
\end{tabular}

\section{6b) Japan}

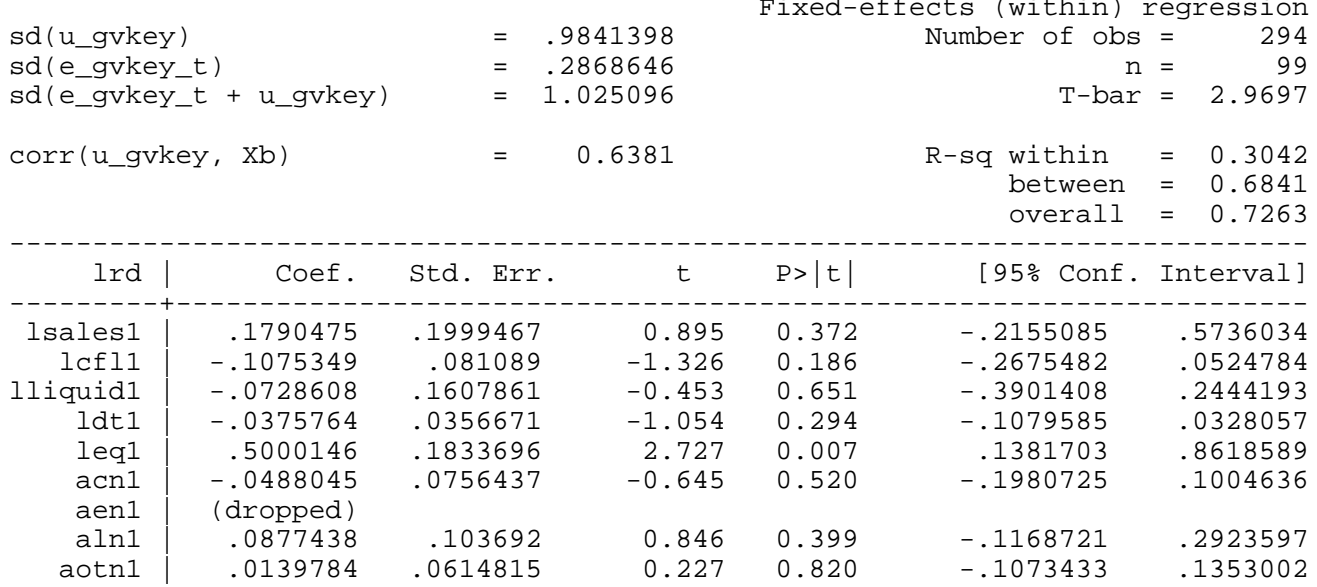

\section{6c) Europe}

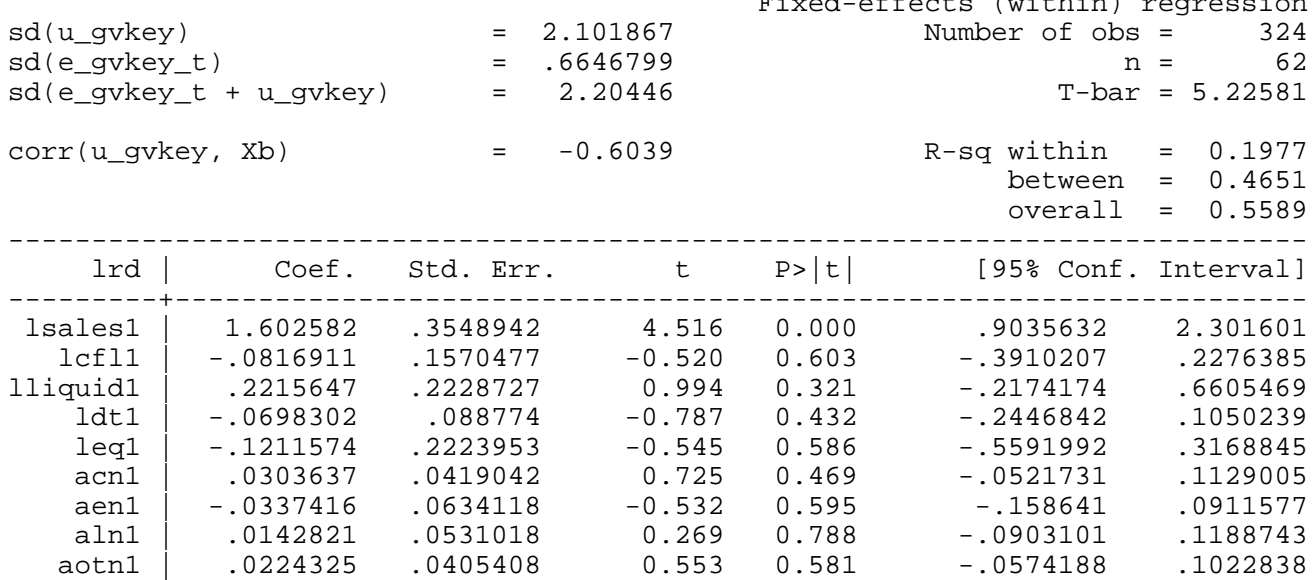

\section{6d) United Kingdom}

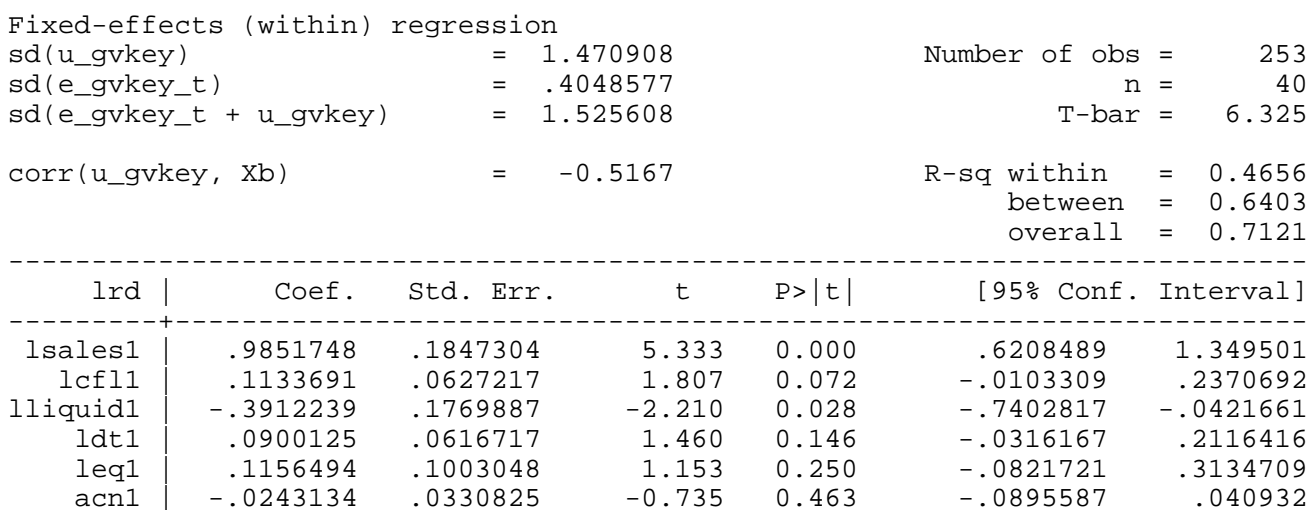




\begin{tabular}{r|rrrrrr} 
aen1 & -.0333319 & .0384292 & -0.867 & 0.387 & -.1091222 & .0424583 \\
$\operatorname{aln} 1$ & .0475676 & .0391488 & 1.215 & 0.226 & -.0296418 & .1247769 \\
$\operatorname{aotn1}$ & .0024467 & .0218877 & 0.112 & 0.911 & -.0407203 & .0456138
\end{tabular}

Table 7 : average R\&D intensity by segment and acquisition behaviour, 1990-91 and 1996-97

\begin{tabular}{|c|c|c|c|c|c|c|c|}
\hline & & \multicolumn{3}{|c|}{ Inactive } & \multicolumn{3}{|c|}{ Active } \\
\hline Segment & & Balanced & Acquirers & ivestors & Balanced & Acquirers & Divestors \\
\hline ENERGY & $\begin{array}{l}(1) \\
(2)\end{array}$ & $\begin{array}{l}0.7 \% \\
0.5 \%\end{array}$ & $\begin{array}{l}0.4 \% \\
0.8 \%\end{array}$ & $\begin{array}{l}1.3 \% \\
--\end{array}$ & $\begin{array}{l}1.9 \% \\
2.3 \%\end{array}$ & $\begin{array}{l}2.1 \% \\
1.6 \%\end{array}$ & $\begin{array}{l}0.7 \% \\
0.4 \%\end{array}$ \\
\hline COMMODITY & $\begin{array}{l}(1) \\
(2)\end{array}$ & $\begin{array}{l}1.7 \% \\
2.5 \%\end{array}$ & $\begin{array}{l}4.1 \% \\
3.3 \%\end{array}$ & $\begin{array}{l}5.2 \% \\
4.1 \%\end{array}$ & $\begin{array}{l}4.6 \% \\
4.5 \%\end{array}$ & $\begin{array}{l}3.8 \% \\
3.8 \%\end{array}$ & $\begin{array}{l}2.4 \% \\
3.0 \%\end{array}$ \\
\hline $\begin{array}{l}\text { LIFE } \\
\text { SCIENCE }\end{array}$ & $\begin{array}{l}\text { (1) } \\
\text { (2) }\end{array}$ & $\begin{array}{r}8.7 \% \\
11.0 \%\end{array}$ & $\begin{array}{r}8.7 \% \\
10.8 \%\end{array}$ & $\begin{array}{l}7.8 \% \\
9.0 \%\end{array}$ & $\begin{array}{l}41.3 \% \\
46.7 \%\end{array}$ & $\begin{array}{r}8.6 \% \\
10.6 \%\end{array}$ & $\begin{array}{l}10.2 \% \\
12.9 \%\end{array}$ \\
\hline $\begin{array}{l}\text { OTHER } \\
\text { CHEMICALS }\end{array}$ & $\begin{array}{l}\text { (1) } \\
\text { (2) }\end{array}$ & $\begin{array}{l}3.4 \% \\
2.4 \%\end{array}$ & $\begin{array}{l}1.2 \% \\
1.7 \%\end{array}$ & $\begin{array}{l}1.6 \% \\
3.9 \%\end{array}$ & $\begin{array}{l}3.0 \% \\
2.7 \%\end{array}$ & $\begin{array}{l}4.1 \% \\
3.5 \%\end{array}$ & $\begin{array}{l}4.3 \% \\
2.1 \%\end{array}$ \\
\hline OTHERS & $\begin{array}{l}(1) \\
(2)\end{array}$ & $\begin{array}{l}3.0 \% \\
2.3 \%\end{array}$ & $\begin{array}{l}2.8 \% \\
2.6 \%\end{array}$ & $\begin{array}{l}3.4 \% \\
7.5 \%\end{array}$ & $\begin{array}{l}2.8 \% \\
2.8 \%\end{array}$ & $\begin{array}{l}3.4 \% \\
2.6 \%\end{array}$ & $\begin{array}{l}5.7 \% \\
3.5 \%\end{array}$ \\
\hline TOTAL & $\begin{array}{l}\text { (1) } \\
\text { (2) }\end{array}$ & $\begin{array}{l}3.0 \% \\
3.1 \%\end{array}$ & $\begin{array}{l}4.0 \% \\
4.1 \%\end{array}$ & $\begin{array}{l}2.3 \% \\
6.2 \%\end{array}$ & $\begin{array}{l}2.5 \% \\
3.0 \%\end{array}$ & $\begin{array}{l}4.7 \% \\
4.8 \%\end{array}$ & $\begin{array}{l}1.4 \% \\
1.4 \%\end{array}$ \\
\hline $\begin{array}{l}(1)=R \& D \text { in } \\
(2)=R \& D \text { in }\end{array}$ & ensit & $\begin{array}{l}1990-9 \\
1996-9\end{array}$ & & & & & \\
\hline
\end{tabular}

Table 8 : Restructuring volumes by industry, region, and firm size.

\begin{tabular}{|c|c|c|c|c|c|c|c|c|c|c|c|}
\hline & & \multicolumn{5}{|c|}{ Small firms } & \multicolumn{5}{|c|}{ Large firms } \\
\hline \multicolumn{2}{|l|}{ Segment } & NA & $\mathrm{JP}$ & EU & UK & Total & US & $\mathrm{JP}$ & $\mathrm{EU}$ & UK & Total \\
\hline \multirow[t]{2}{*}{ ENERGY } & Acquisitions & 48 & 1 & 7 & 10 & 66 & 278 & 4 & 141 & 72 & 495 \\
\hline & Divestitures & 38 & 0 & 3 & 10 & 51 & 396 & 2 & 155 & 104 & 657 \\
\hline \multirow[t]{2}{*}{ COMMODITY } & Acquisitions & 54 & 0 & 10 & 6 & 70 & 297 & 42 & 122 & 41 & 502 \\
\hline & Divestitures & 26 & 0 & 3 & 4 & 33 & 251 & 4 & 57 & 11 & 323 \\
\hline LIFE & Acquisitions & 167 & 5 & 13 & 53 & 238 & 195 & 35 & 220 & 56 & 506 \\
\hline SCIENCE & Divestitures & 134 & 4 & 5 & 11 & 154 & 91 & 11 & 113 & 73 & 288 \\
\hline
\end{tabular}




\begin{tabular}{lllllll|rrrrr}
\hline & & & & & & & & & & \\
OTHER & Acquisitions & 156 & 5 & 8 & 69 & 238 & 353 & 61 & 269 & 205 & 888 \\
CHEMICALS & Divestitures & 111 & 0 & 3 & 17 & 131 & 215 & 13 & 118 & 159 & 505 \\
& & & & & & & & & & & \\
OTHERS & Acquisitions & 47 & 0 & & 10 & 57 & 203 & 13 & 177 & 170 & 563 \\
& Divestitures & 32 & 0 & & 11 & 43 & 156 & 1 & 127 & 79 & 363 \\
& & & & & & & & & & & \\
\hline Toal & Acquisitions & 472 & 11 & 38 & 148 & 669 & 1,326 & 155 & 929 & 544 & 2,954 \\
& Divestitures & 341 & 4 & 14 & 53 & 412 & 1,109 & 31 & 570 & 426 & 2,136 \\
\hline
\end{tabular}

Note: Large firms are those with sales greater than the median value of sales for the sample period, \$ 682 million.

Table 9: Fixed effects regressions for the pooled sample, capital expenditure

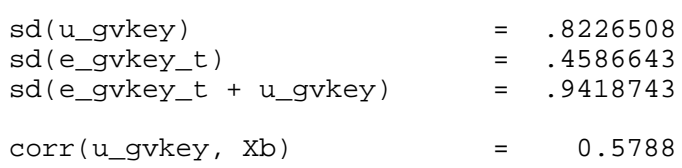

\begin{tabular}{|c|c|c|c|c|c|c|}
\hline lcapx & Coef. & Std. Err. & t & $P>|t|$ & [95\% Conf. & Interval] \\
\hline lsales 1 & .3612604 & .0562045 & 6.428 & 0.000 & .251011 & .4715099 \\
\hline $\operatorname{lcfl1}$ & .1800896 & .0235896 & 7.634 & 0.000 & .1338167 & .2263625 \\
\hline lliquid1 & .1897569 & .0430159 & 4.411 & 0.000 & .1053779 & .2741359 \\
\hline $1 d t 1$ & .0306538 & .0165496 & 1.852 & 0.064 & -.0018095 & .0631171 \\
\hline leq1 & .2615757 & .0399474 & 6.548 & 0.000 & .1832158 & .3399355 \\
\hline $\operatorname{acn} 1$ & .0018894 & .0254247 & 0.074 & 0.941 & -.0479831 & .051762 \\
\hline aen1 & -.0023574 & .0192079 & -0.123 & 0.902 & -.0400352 & .0353204 \\
\hline$a \ln 1$ & .0342525 & .0275279 & 1.244 & 0.214 & -.0197457 & .0882507 \\
\hline $\operatorname{aotn} 1$ & .0226831 & .0150018 & 1.512 & 0.131 & -.0067441 & .0521102 \\
\hline
\end{tabular}


Figure 1a:

R\&D intensity, cumulative density, commodity chemicals

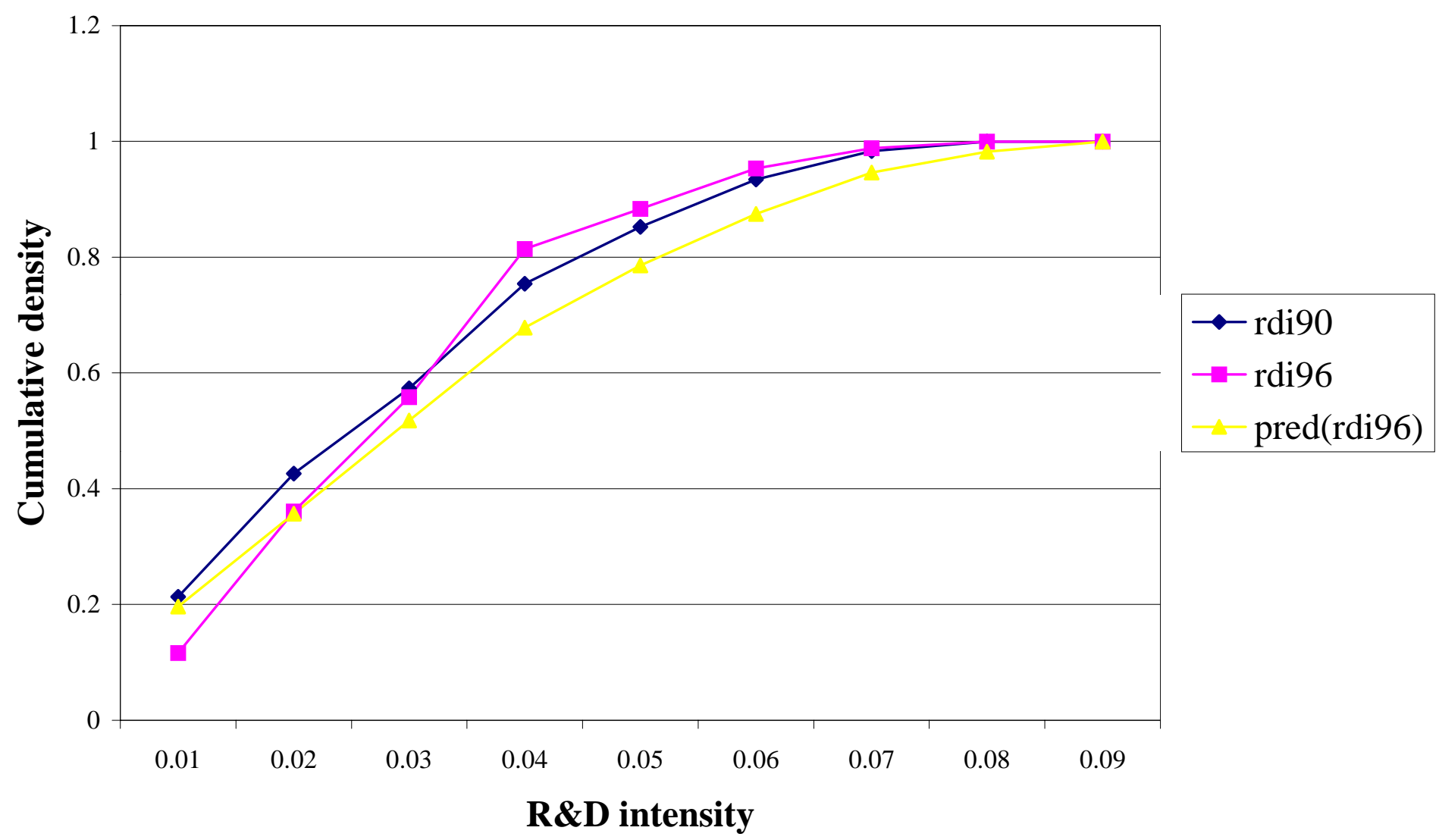


Figure 1b:

R\&D Intensity, Cumulative Density, Life Sciences

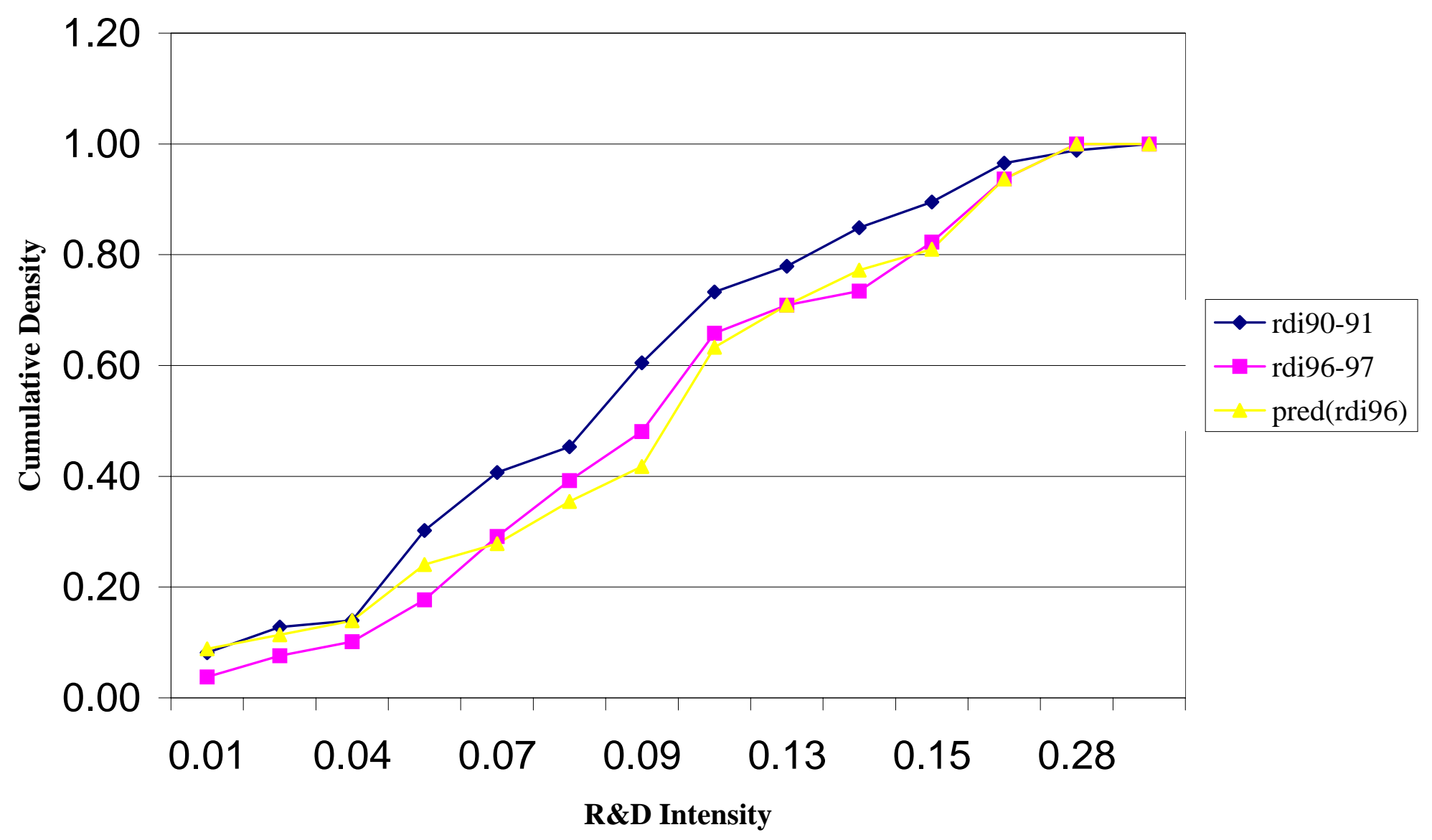


Figure 1c:

R\&D Intensity, Cumulative Density, Other Chemicals

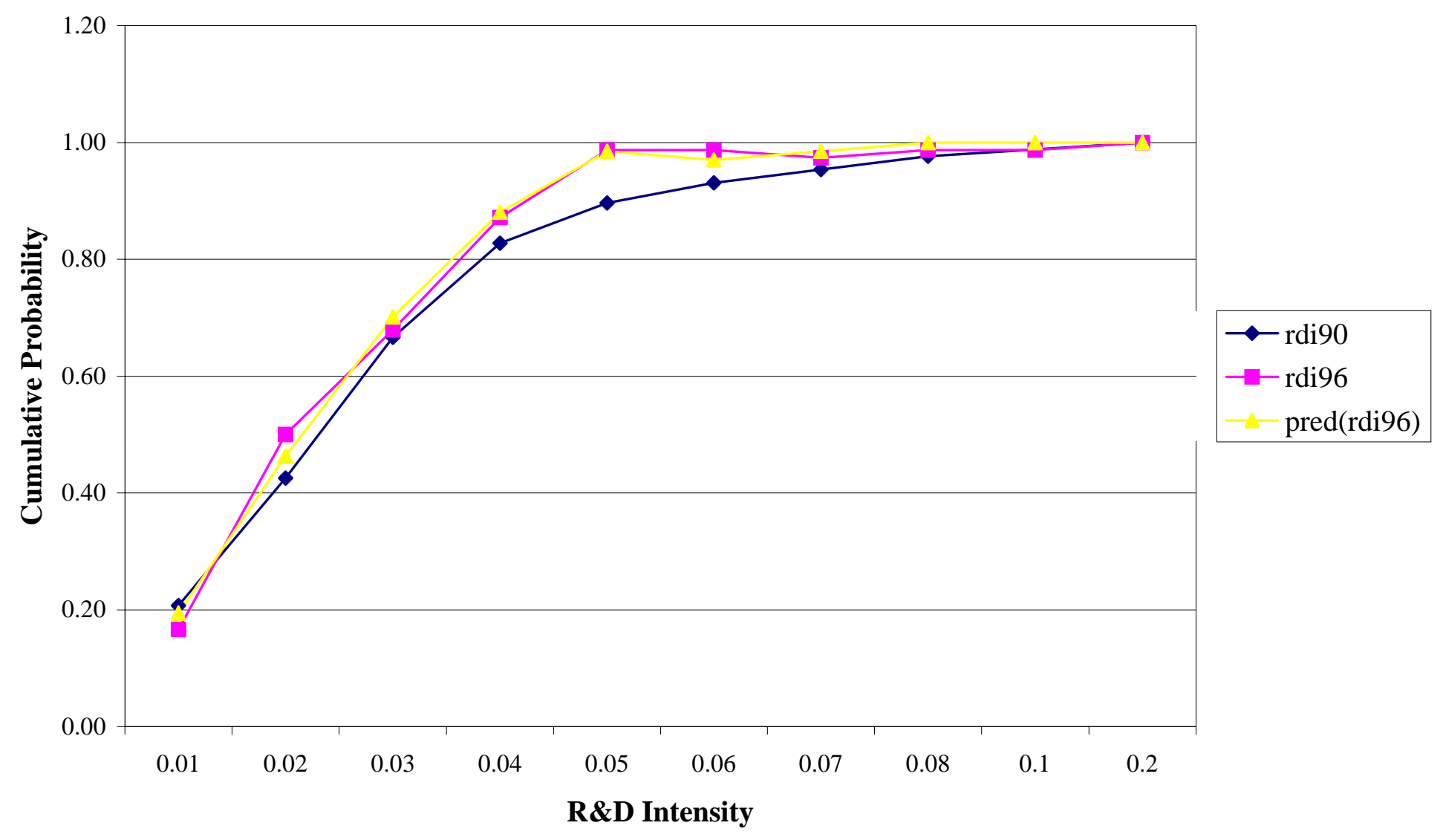


Table 10: R\&D intensity, by segment, 1990-91 and 1996-97.

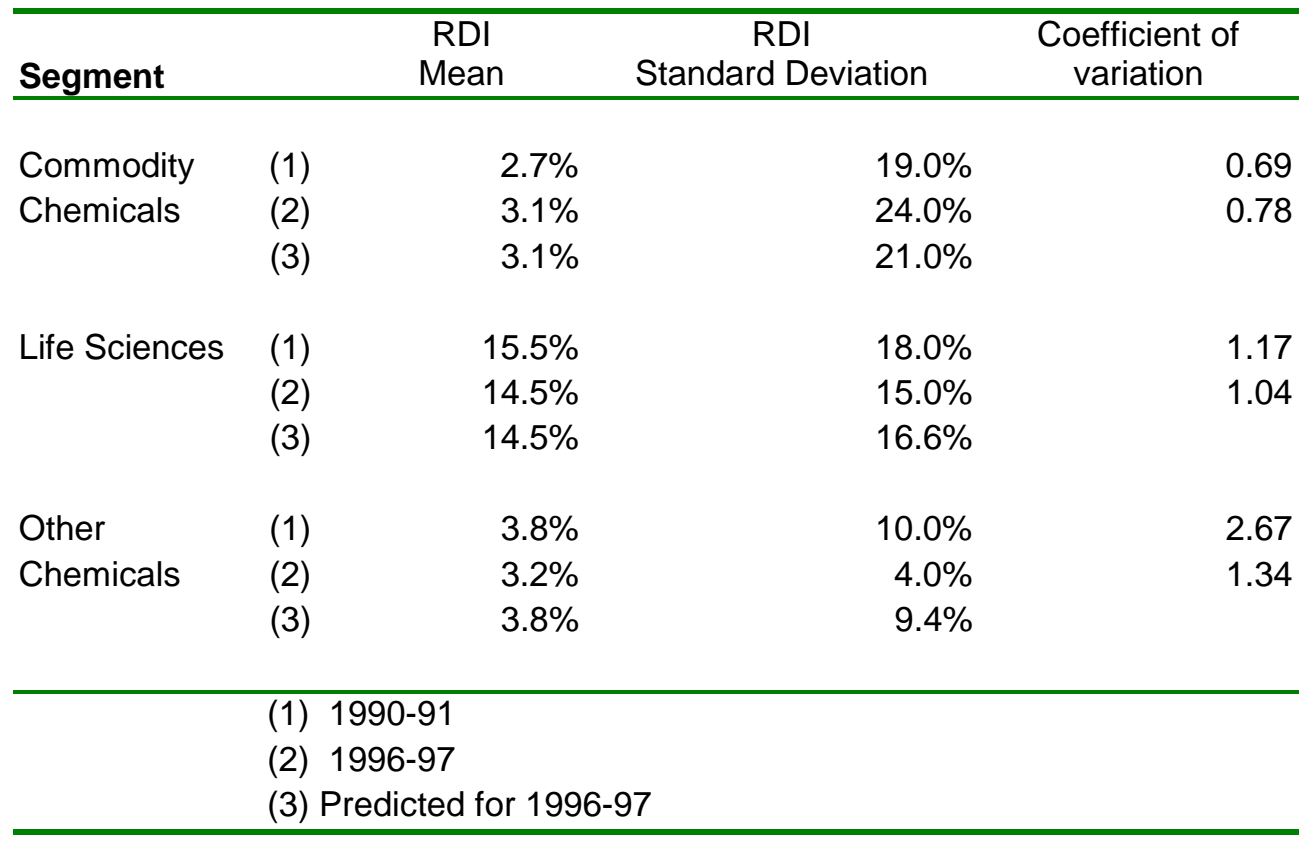

